\title{
WORKING'PAPERS
}

Macroeconomic Adjustment and Frowth

Country Economics Department

The World Bank

October 1991

WPS 795

\section{Economic Stagnation, Fixed Factors, and Policy Thresholds}

\section{William Easterly}

Economic policies, not initial conditions, detarmine whether countries stagnate. The black market premium on foreign exchange is an important factor in stagnation. 


\section{WORKING PAPERS}

\section{Macroeconomic Adjustment and Growth}

WPS 795

This paper - a product of the Macrocconomic Adjustment and Growth Division, Country Economics Department - is part of a larger effort in PRE to assess the effect of national policies on long-run growth. This research was funded by the World Bank's Research Support Budget under research project "Do National Policies Affect Long-Run Growth?" (RPO 676-66). Copics are available frec from the World Bank, 1818 H Sircet NW, Washington DC 20433. Please contact Rebecca Martin, room N11-053, extension 39065 (39 pages). October1991.

Many developing countries have experienced cconomic stagnation. Africa had negative per capita growth in the 1970s and 1980s, and Latin America in the 1980s. Per capita growth was significantly grcatcr than zcro only in 41 of 87 developing countries in $1950-85$, but it was significantly positive in all $O E C D$ countrics.

Analysis of decade-long growth rates in all countries shows a striking regularity: Episodes of rapid growth are limited largely to a middlc range of initial income; neither very poor nor very rich countries experience rapid growth. Episodes of negative growth are limited to low and middle-income countries.

Easterly develops a simple model that sheds light on this historical experience. The model has two familiar elements from the growth literature: (1) a Stone-Gcary utility function (saving is low at low incomes), and (2) fixed factors with the marginal product of capital bounded away from zero. The sccond property is derived by assuming an clasticity of substilution greater than one between an exogenous labor input and a broad concept of capital. Easterly extends the model to consider multiple capital goods and public capital.

Hc finds that stagnation because of fixed factors is consistent with an array of statistical cvidence. Eccnomic policics - not initial conditions - determinc whether countries stagnatc. The black market premium on foreign exchange is particularly helpful in cxplaining stagnation.

Empiric. ' results show that growth first accelerates and then falls as income rises. Results confirm that initial income and policy variables have a different effect on whether a country stagnates than they do on the rate of growth once it starts growing, as expected from the distinction between steady-state and transitional cffects.

These results suggest that cross-section growth regressions may be misspecificd because of the nonlinearity inherent in the possibility of stcady-state stagnation. 


\section{TABLE OF CONTENTS}

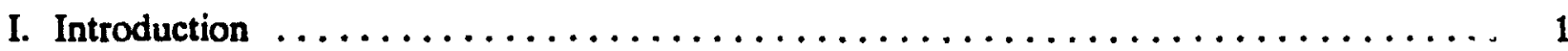

II. Evidence on output stagnation and growth $\ldots \ldots \ldots \ldots \ldots \ldots \ldots \ldots \ldots \ldots \ldots, 3$

III. A model of policy-induced stagnation $\ldots \ldots \ldots \ldots \ldots \ldots \ldots \ldots \ldots \ldots \ldots \ldots$

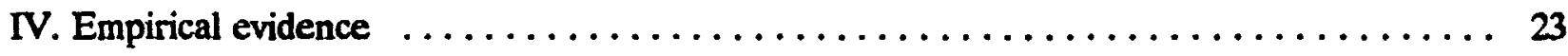

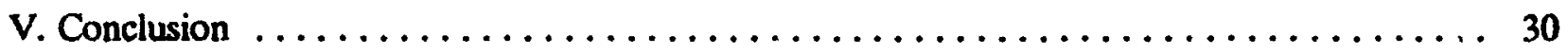

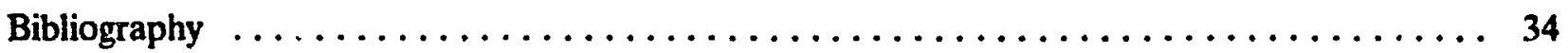

I have benefitted from comments of Robert Barro, Jose de Gregorio, Stanley Fischer, Robert King, Michael Kremer, Ross Levine, Lant Pritchett, Sergio Rebelo, Dani Rodrik, Alwyn Young and Heng-Fu Zou, as well as of participants in a seminar at University of Maryland and in the Northwestern University Summer Workshop. I am grateful for research assistance from Piyabha Kongsamut and Maria Cristina Siochi. 


\section{Introduction}

Stagnation due to fixed factors bulks large in both the old and the new literature on growth. The diminishing returns to endogenous factors with other factors fixed exogenously is at the heart of classical and neoclassical theories of growth from Maithus to Solow. Malthus postulated a model with population growth constrained at zero because of the dimininishing marginal product of labor with land held constant. Ricardo put forward his model of rising rents and landlord enrichment based on a fixed supply of land. Mill recognized that other economic forces could offset diminishing returns to fixed factors, but the outcome was far from certain:

Whether, at the present or any other time, the produce of industry proportionally to the labor employed, is increasing or diminishing ... depends upon whether population is advancing faster than improvement, or improvement thati population. ${ }^{1}$

Mill seems to be a precursor to the broad notion of capital in the current growth literature in that his "improvement" includes inventions, institutional change, and education and trainis:s.

Solow could afford to ignore land as a factor of production; in his model it is diminishing returns to capital with exogenous labor growth that prevents sustained per capita growth. Thus, his famous conclusion that exogenous technological change, the "residual", was the force behind per capita growth. However, in retrospect, the predictions of the model seem to have had decidedly mixed success in describing postwar economic development. The prediction of the model that poor countries would grow faster than rich countries seems to have been confirmed among the subsct of advanced countries (or among regions of one rich country) but not among ail countries (Baumol and Wolff (1988), Barro and Sala-I-Martin (1989)). Some empirical studies have found that growth is inversely related to per capita income when policy variables are included (Barro (1991), Romer (1989), Levine and Renelt (1990)).

The new literature on growth makes growth endogenous by postulating externalities to human or physical capital that overwhelm diminishing returns to fixed factors (Romer (1986,

\footnotetext{
'quoted in Abramowitz (1989), p.6
} 
1990), Lucas (1988)). Another strand of the literature simply omits fixed factors (Rebelo (1991), King and Rebelo (1990), Barro (1990)), arguing that even labor can be increased endogenously through investment in human capital, so that "everything is capital." This literature bears a resemblance to the development literature of the 1940's and 50's, which also argued that production depended only on capital, albeit for much different reasons .- in the famous Lewis surplus labor model, for example, an infinitely elastic supply of labor makes (physical) capital the only constraint on output. ${ }^{2}$

The new literature on growth has also begun to address the apparent predicament of the poorest countries. Models with multiple equilibria are of particular interest here. Azariadis and Drazen (1990) show how a threshold requirement in the externality generated by human capital accumulation can yield multiple steady states in per capita growth, some characterized by low growth and no human capital investment, others by high growth and high investment in human capital. Similarly, using a model of endogenous fertility, Becker, Murphy, and Tamura (1990) postulate an increasing marginal product of human capital over low income ranges to genciate alternative steady states of high fertility and zero per capita growth and low fertility and high per capita growth. Murphy, Shleifer, and Vishny (1988) present a model with coordination externalities in which a "big push" may be needed to start development in a low income economy. In all of these models, initial conditions can play a critical role in whether a country develops. Again, these models echo earlier strands of the development literature -- e.g. the "low-level development trap" of Nelson (1956), and the "big push" theory of Rosenstein-Rodan (1947).

Other endogenous growth models supply other elements useful to understand the apparent stagnation of the poor countries without reference to increasing returns or initial conditions. Rebelo (1991b) and Easterly (1990a) postulate models in which the rate of saving

\footnotetext{
2The models continue to be influential up to the present. For a recent exmple, sec Taylor (1989).
} 
rises with income, in the tradition of the Stone-Geary consumption function. Rebelo (1991b) presents strong evidence for this hypothesis with analysis of cross-country saving rates. A country can then be stuck in a zero growth equilibrium with "subsisterce" income and zero saving. Jones and Manuelli (1990) present an endogenous growth model in which the production function exhibits constant returns and diminishing marginal products of all factors, but the marginal product of capital is bounded away from zero. ${ }^{3}$ This model has two attractive features: (1) endogenous growth can be explained without any reference to market failure or externalities; (2) the model can generate either stagnant per capita income or sustained growth depending on the parameters. In this paper, we will combine the elements of Stone-Geary consumption behavior with a Jones-Manuelli production function to analyze possible causes of growth and stagnation.

The paper is organized as follows. In section II, we present some descriptive statistics on the phenomenon of income stagnation. In section III, we present a model that explains stagnation and growth by policies such as income taxes. Some variations of the model to consider distortionary policies and government investment are also presented. Section IV presents some empirical results which relate the probability of stagnation to policy variables. Section V concludes.

\section{Evidence on output stagnation and growth}

Although the euphemism "developing countries" is universally used to describe poor countries, it is far from clear that sustained per capita growth is underway in all countries. Determining long-run growth tendencies is problematic because of the short time-series available for most countries. Reynolds (1985) concluded that 7 of 40 developing countries whose long-run

\footnotetext{
3The earlier growh literature had also considered this type of model (Gale and Suthertand (1968), Kurz (1968)).
} 
experience he analyzed had not begun sustained per capita growth. The 1991 World

Development Report of the World Bank shows negative or zero per capita growth for 19

develc sing countries from 1965-89." All developed countries had per capita growth rates well

above zero over this period. Income levels at or near subsistence in some low-income countries

could also be taken as prima facie evidence that those countries have never grown. ${ }^{5}$

Even for thase countries that display positive per capita growth, $i \hat{\imath}$ is unclear whether this represents an underlying trend or merely random variation around a stationary income level. To test this for individual countries, the log change in real per capita GDP was regressed on a constant and then the significance of this constant was assessed. The results are shown in table 1. Only 41 out of 87 developing countries had significant positive per capita growth in the postwar period. In other words, growth is so low and/or the variation in output in 46 of the 87 countries is so great relative to the trend that it is impossible to discern whether the countries are growing or not. ${ }^{7}$ By contrast, all OECD countries had significant growth rates (not show: in the table).

\footnotetext{
The countries are Ethiopia, Chad, Tanzania, Zaire, Madagascar, Uganda, Zambia, Niger, Togo, Benin, Central African Republic, Ghana, Mauritania, Bolivia, Senegal, Peru, El Salvador, Jamaica, and Argentina. Venezuela, Litya, and Kuwait also had negative growth but are excluded because their economies are dominated by oil. Many other countries that probably had negative grown are excluded because of unavailablity of data: Afghanistan, Bhutan, Kampuchea, Liberia, Myanmar, Sudan, Vietnam, Lebanon, Miongolia, Nicauragua, Iraq, and Romania.

The 1990 World Developmens Repon defines US\$375 per capita consumption as the poverty line in 1985 PPP prices. 10 countries were below this level in 1988 acoording to Summers and Heston (1988). This argument kas suggested by Lant Pritchett.

${ }^{6}$ Countries dominated by oil are excluded. An eartier version of these results is contained in Easterty (1990a).

7 To discriminate between insignificance due to low growth and that due to high variation, we calculate the power of the teat, as suggested by Andrews (1989). If the abcolute value of true growh is les than the coefficient value under "region of low power", the probability of failing to reject is greater than 50 percent. A high value of this coefficient implies a weak teat. For example, 13 of 28 countries with inaignificant ponitive growh have a region of low power spannag more than $[-1,1]$, which means that even if the true growth rate were above 1 percent (or les than -1 percent), there would still be a 50 percentehance the teat would fail to reject zero growth. For these countriea, there is little chance of detecting whether growth is occurring - the test is indeed very weak. For the other countries, the region of low power is within [-1,1]. This implies for those countries that there is a high probability of failing to reject zero growth only if growth is in fact close to zero. This technique was suggested by Lant Pritchett. Detailed results are avilable upon request.
} 
Table 1

Per capita growth performance of developing countries, 1950-85

\begin{tabular}{|c|c|c|}
\hline Negative growth & $\begin{array}{l}\text { Positive but } \\
\text { insignificant growh }\end{array}$ & $\begin{array}{l}\text { Positive and } \\
\text { significant grow.th }\end{array}$ \\
\hline $\begin{array}{l}\text { Afghanistan } \\
\text { Angola } \\
\text { Benin } \\
\text { Bolivit } \\
\text { Burundi } \\
\text { Central African Rep. } \\
\text { Chad } \\
\text { Ghana } \\
\text { Guinea } \\
\text { Guryana } \\
\text { Madagascar } \\
\text { Mali } \\
\text { Mozambique } \\
\text { Senegal } \\
\text { Somalia } \\
\text { Sudan } \\
\text { Zaire } \\
\text { Zambia }\end{array}$ & $\begin{array}{l}\text { Argentina } \\
\text { Bangladeah } \\
\text { Chile } \\
\text { Congo } \\
\text { Cote d'Ivoire } \\
\text { El Salvador } \\
\text { Ethiopia } \\
\text { Fiji } \\
\text { Gustemala } \\
\text { Haiti } \\
\text { Honduras } \\
\text { Jamaica } \\
\text { Kenya } \\
\text { Liberia } \\
\text { Mauritania } \\
\text { Mauritius } \\
\text { Nepal } \\
\text { Nicaragua } \\
\text { Nigeria } \\
\text { Papua New Guinea } \\
\text { Peru } \\
\text { Philippines } \\
\text { Rwanda } \\
\text { Sierra Leone } \\
\text { The Gambia } \\
\text { Togo } \\
\text { Uganda } \\
\text { Uruguay }\end{array}$ & $\begin{array}{l}\text { Ageria } \\
\text { Barbados } \\
\text { Botswana } \\
\text { Brazil } \\
\text { Burtina Faso } \\
\text { Cameroon } \\
\text { China } \\
\text { Colombia } \\
\text { Costa Rica } \\
\text { Cyprus } \\
\text { Dominican Republic } \\
\text { Ecuador } \\
\text { Egypt } \\
\text { Gabon } \\
\text { Hong Kong } \\
\text { India } \\
\text { Indonesia } \\
\text { Jordan } \\
\text { Korea } \\
\text { Lesotho } \\
\text { Malawi } \\
\text { Malaysia } \\
\text { Maita } \\
\text { Mexico } \\
\text { Morocco } \\
\text { Myanmar } \\
\text { Pakistan } \\
\text { Panama } \\
\text { Paraguay } \\
\text { Singapore } \\
\text { South Africa } \\
\text { Sri Lanka } \\
\text { Suriname } \\
\text { Swaziland } \\
\text { Syria } \\
\text { Takwan } \\
\text { Tanzania } \\
\text { Thailand } \\
\text { Tunisia } \\
\text { Turkey } \\
\text { Zimbabwe } \\
\text { Lim }\end{array}$ \\
\hline
\end{tabular}


Although there is doubt about the long-term trend of many countries, there is no doubt about recent stagnation in most developing countries. Table 2 shows trowth rates by decade $f$ or regional groups of developing countries. The African countries (almost all low-income economies) stagnated in both the 1970's and 1980's. Latin America stagnated in the 1980's in the aftermath of the external debt crisis. South Asia has done better than Africa and Latin America, but only East Asian countries (almost all middle-income economies) compare favorably to OECD countries.

Figure 1 shows decade-long per capita growth rates graphed against initial per capita income level. Two striking facts are evident. One is that the phenomenon of negative growth is limited to developing countries. The second is that the $\mathrm{L}_{2}$ per boundary to the distribution displays a bell shape -- the most rapidly growing countries are at middle income levels. (This is more evident in figure $1 \mathrm{~b}$ which displays a logarithmic scale). Contrary to the predictions of the Solow model, even the "best" poor countries grow less rapidly than the "best" middle-income countries. However, beginning with middle-income levels, the "best" growth rates decline with income level. The rapid growth of middle-income countries mirrors the earlier experience of "catch-up" of late industrializers such as Japan and Russia, as famously noted by Gerschenkron (1962). ${ }^{8}$ To see whether this pattern is due to the scarcity of observations in the tails of a bivariate normal distribution, Figure 1c graphs the cbservations from the sample stratified into equai groups. We still see a strong tendency for the upper boundary of the graph to show a bell shape.

\footnotetext{
"The "catch-up" phenomenon was attributed by Gershenkron to, among other things, the advantage that latecomers have in borrowing technology which they do not need to develop themselves. For recent discusaions of the dyuamica of technological diffusion and adoption, sec Jovanovic, Lach (1990), Wan (1990), and Parento and recoot (1991).
} 
Table 2

Growth rates of output per capita, 1960 to 1989

GDP per capita growth Annual averages

\begin{tabular}{lccc} 
Country group & $1960-70$ & $1970-80$ & $1980-89$ \\
\cline { 2 - 3 } & & & -1.7 \\
Low and middle-income economies & 2.2 & 0.6 & 0.1 \\
$\quad$ Low-income economies & 1.2 & -02 \\
$\quad$ Middle-income economies & 3.0 & 2.7 & 0.3 \\
Sub-Saharan Alrica & 1.4 & -0.2 & -0.5 \\
East Asia & 3.6 & 4.6 & 3.6 \\
South Asia & 1.4 & 1.4 & 2.3 \\
Latin America and the Caribbean & 2.4 & 2.0 & -1.2 \\
OECD & 4.1 & 2.3 & 2.0 \\
\hline
\end{tabular}

All averages are unweighted. Cil-dominated countries have been excluded.

Regional aggregates include only developing countries.

Sources: WDR 1981, 1982, and 1990. 
figure 1(a)

Per capita Income and growth (Linear scallng)

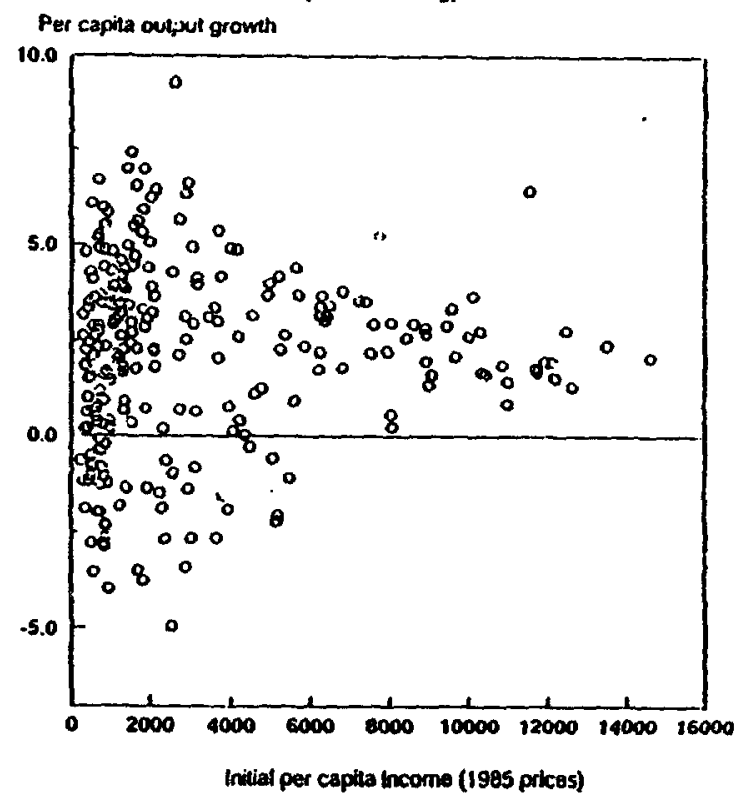

figuro 1 (b)

Per capita income and growth (Loyjarithmic scaling)

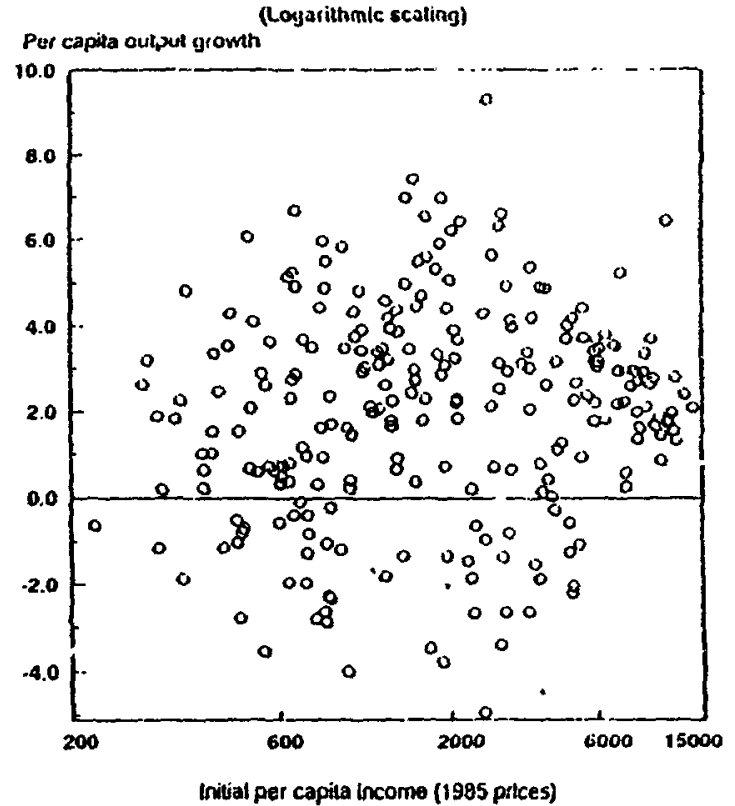

Figure 1 (c)

Per capita income and growtl

(Logarithuste scaling)

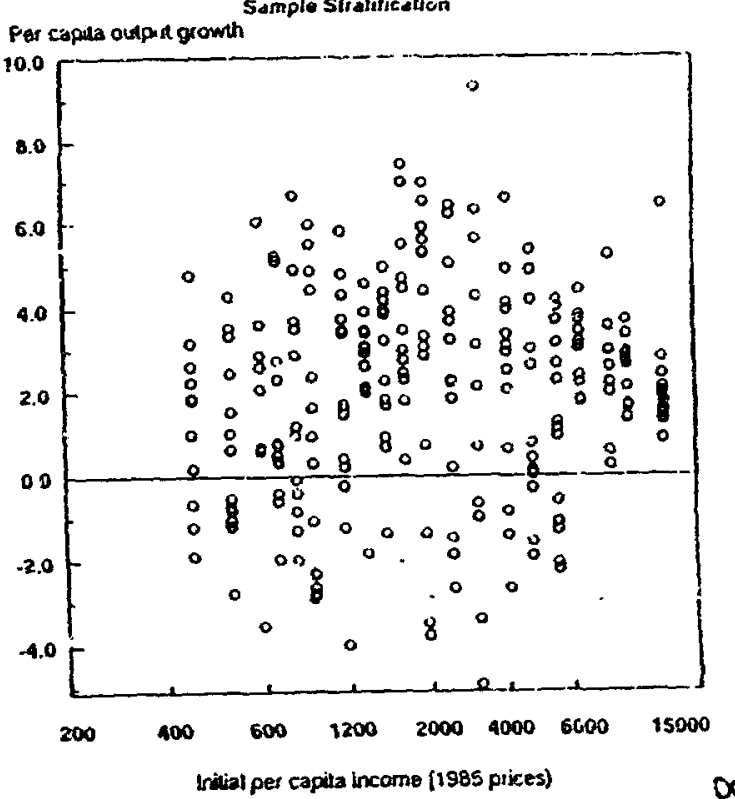


To assess whether the patterns presented are statistically significant, Table 3 shows a contingency table and tests for the ir lependence of income and growth under various classifications. With a 3-way classification (low, middle, and high income, and high positive, mediun positive, and negative growth) the independence of growth and income is decisively rejected. This is an interesting contrast to the well-known lack of significance of the simple linear coitelation between growth and income (in this sample, ihe correlation coefficient is .06)..$^{9}$ The pattern that high growth rates are disproportionately $\mathrm{r}$-presented among middle income countries is confirmed statistically $\cdot t$ the 5 percent level, as is the relative absence of negative growth at high incomes..$^{10}$

\section{A model of policy-induced stagnation}

In this section we present a model where policy and model parameters determines whether a country is in one of 3 possible long-run equilibria: (1) zero per capita growth with income at subsistence; (2) zero per capita growth with income above subsistence; or (3) positive per capita growth. Only one equilibrium at a time exhibits saddle point stability, so the outcome is well-defined. We show how the model displays the alternative equilibria depending on the overall rate of incomc tax. We then consider some extensions of the model to the case of

\footnotetext{
This lack of simple correlation between per capita insome and growth was ncted by, among others, Summers and Heston (1988) and Barro (1991).

${ }^{10}$ Altemative breakdowns of growth and income were tested to assess the robust. alternatively as greater than 4 percent and greater than 3 percent, disproportionate representation of high growh at middle ircomes is confirmed even more strongly. With the income breakpoints at 700 and 7000 , a tendency toward high growth at middle incomes is confirmed if high growth is defined as greater than 3 or 4 percent, but not 5 percent. With income breakpoints at 800 and 6200 (chosen as the 1980 per capita incomes corresponding to the bordertine low and high income countries in the WDR), high middle income growth is again confirmed with the 3 and 4 percent definitions, but gnt the 5 percent. We conclude the result of greater frequency of high growth at middle incomes is reasonably robust. The general independence of growh and initial income (i.e. also including the lack of negative growth at high income) is rejected at the 1 percent levt with all of these breakdowns.
} 
Table 3:

Contingency table of per capita income and per capita growth, decade averages

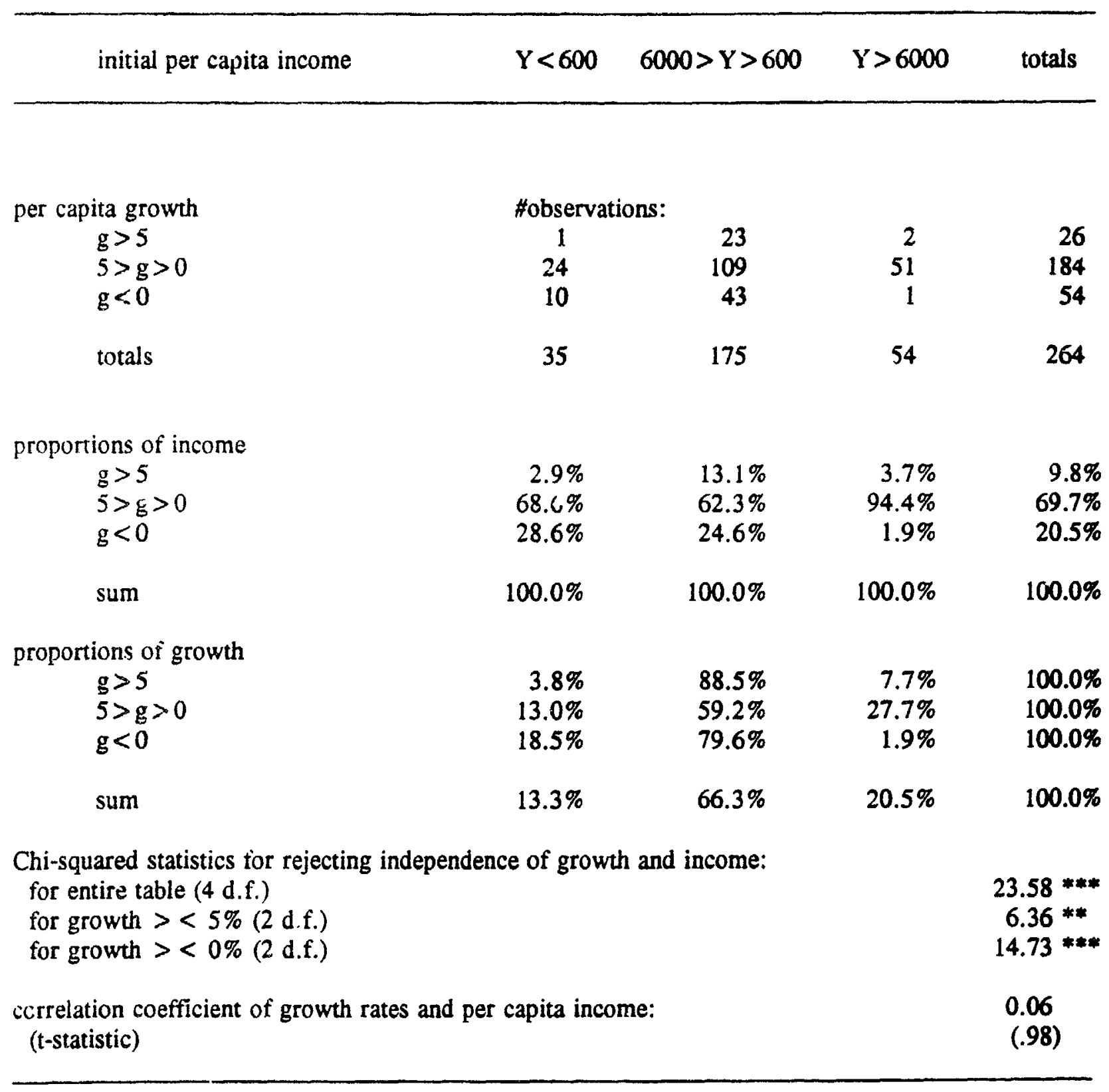

Sources: growh, World Bank data;per capita income (85 prices), Summers and Heston (1988) *** significant at $1 \% * *$ significant at $5 \%$ 
multiple types of capital goods, which is relevant for the analysis of policies that affect resource allocation. Two such policies that are considered are differential taxes on investment goods, and government investment in infrastructure.

\section{The model}

The production function for the single good is a conventional CES function for capital $K$ and labor L:

$$
Y=A\left(\gamma \mathbb{R}^{\epsilon}+(1-\gamma) L^{\epsilon}\right)^{\frac{1}{\epsilon}}
$$

The elasticity of substitution between capital and lahor is $1 /(\epsilon-1)$. The only difference from a conventional neoclassical specification is that capital is defined more broadly than just fixed physical assets. As in Rebelo (1991b) and Barro (1990), we have in mind a broad concept of

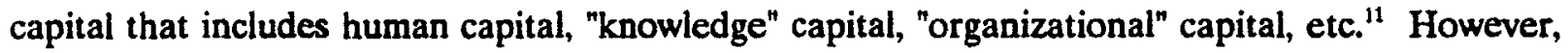
unlike Rebelo and Barro, but like Jones and Manuelli (1990), a fixed factor like "raw" labor still has a role in production. ${ }^{12}$

With such a broad concept of capital in mind, it is assumed $\epsilon>0$, i.e. the elasticity of substitution between capital and labor is greater than one. It is true that a great deal of econometric evidence suggests that this elasticity is less than or equal to one. However, if (1) is the true relation where $K$ is defined to be "broad" capital, the estimation of (1) with only physical capital and labor included would result in biased coefficient estimates, because of the omission of

\footnotetext{
"Since some or all of these nontraditional types of capital are embodied in people, $\mathrm{K}$ should be thought of as including an element $h L$ where $h$ is embodied capital per person. We ignore this complication to simplify the presentation.

${ }^{12}$ Another production function that satisfic the Jones-Manuelli property is $\mathrm{Y}=\mathrm{AK}+\mathrm{BK} \mathrm{L}^{1 / 4}$ (dubbed the "Sobelow function" by Sala-i-Martin (1990) because it is a linear combination of the Rebelo and Solow models).
} 
other non-physical types of capital. A large substitution elasticity is plausible if we think of laborsaving innovation (traditionally considered exogenous) as a way of substituting physical capital, human capital, and "knowledge" for labor. ${ }^{13}$

With an elasticity greater than one, this production function obeys the Jones-Manuelli property that the marginal product of capital approaches a nonzero limit as the capital-labor ratio goes to infinity. Specifically, if $\epsilon>0$, then:

$$
\lim _{k \rightarrow \infty} \quad \frac{\partial y}{\partial k}=A \gamma^{\frac{1}{\epsilon}}
$$

where $\mathrm{k}$ is the capital-labor ratio, and $\mathrm{y}$ is per capita income.

It is assumed that infinitely-lived producer-consumer dynasties maximize the per capita welfare of themselves and their descendants:

$$
\max \int_{0}^{\infty} e^{-\rho t} \frac{\left(c-c_{s}\right)^{1-\sigma}-1}{1-\sigma} L^{\beta} d t
$$

Utility is an isoelastic function of per capita consumption in excess of a "subsistence" level of $c_{2}$.

The labor term in the intertemporal utility function reflects the weight placed on numbers of descendants vis-a-vis the per capita utility of those descendants, as in Rebelo (1991b) and Becker and Barro (1988). If $\beta$ is equal to zero, then only the per capita welfare of future discendants is considered. If $\beta=1$, then the aggregate welfare of descendants is considered -- one

\footnotetext{
${ }^{13}$ This function also has the apparently counter-intuitive property that neither input is strictly essential, i.e. there could still be positive production with zero labor. However, keeping the broad definition of capital in mind, this does not imply some 21 st century fantary of machines doing all the wort. Capital includes human capital embodied in persons.
} 
is indifferent between an increase in aggregate dynasty "income" because of more descendants and an increase due to higher per capita "income" of an unchanged number of descendants.

We assume that income is taxed by the government at rate $\tau$. Per capita consumption is constrained by:

(4) $\quad c=(1-\gamma) A\left(\gamma k^{\epsilon}+1-\gamma\right)^{\frac{1}{\epsilon}}-1$

where $i$ is investment per capita. The evolution of the capital-labor ratio is given by:

$$
k=1-(\delta+\eta) k
$$

where $\eta$ is the rate of exogenous labor growth.

The first-order conditions yield the following equation for the growth of consumption:

6)

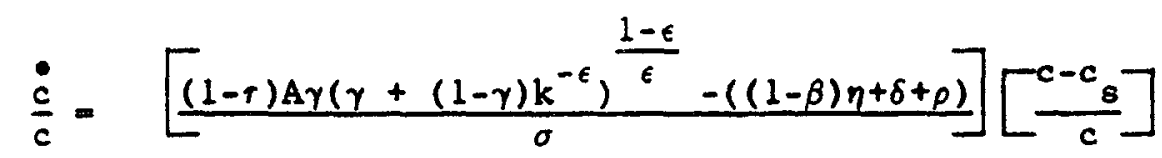

The first expression in brackets is the familiar condition that growth of per capita consumption is given by the net marginal product of capital less the discount rate and labor growth rate (adjusted by $\beta$ ), times the intertemporal elasticity of substitution. The second expression in brackets is the ratio of "excess" (i.e. above subsistence) consumption to total consumption. This term will be close to zero with low consumption and close to one with high consumption.

Equation (6) displays two possible zero-growth equilibria. One is the "modified golden rule" equilibrium where the net marginal product of capital (the marginal product less depreciation) is equal to labor growth (adjusted by $\beta$ ) plus the discount rate. The other is the 
subsistence equilibrium where consumption is equal to subsistence consumption $c_{\mathbf{y}}$. We will see that at most one of these can be stable, and that the tax rate will determine which one is stable, if either. Unlike nonconvex models, initial conditions do not affect the outcome. ${ }^{14}$

The value of the capital-labor ratio at subsistence will be given by the $k$, that satisfies the condition that subsistence consumption is just equal to after-tax income less the investment required to replace depreciated capital and keep up with labor growth.

$$
c_{s}=(1-\tau) A\left[\gamma k_{s}^{\epsilon}+1-\gamma\right]^{\frac{1}{\epsilon}}-(\delta+\eta) k_{s}
$$

This equation could have two solutions for $\mathrm{k}_{\text {; }}$ : one less than the "golden rule" consumptionmaximizing $\mathrm{k}$, and one greater. The lesser one, where the derivative of consumption with respect to $\mathrm{k}$ is positive, is the relevant one (the higher one will be dynamically inefficient and unstable). It is also conceivable that (7) would have no solution -- i.e. subsistence is not feasible. There will always be some $\tau$ that implies infeasibility of subsistence -- this range of $\tau$ is ignored here.

From (7), we can show that the subsistence capital stock will be positively related to $c_{n}, \tau$, $\mathrm{n}$, and $\delta$. A higher subsistence requirement, higher taxes, higher labor growth, and higher depreciation all force the consumer to accumulate more capital to satisfy her subsistence requirements.

\footnotetext{
${ }^{14}$ Models with muitiplicity of equilibria and dependence on initial conditions inctude Murphy, Shleifer and Vishny (1989), Becker, Murphy, and Tamurs (1990) and Azariadis and Drazen (1990). See also the discussion in Srata-i-Martin (1990). With nonconveitiel in the present model, whether the economy grows or stagmates would depend on initial conditions, since the marginal product curve would intersect the time preference line in more than one place. However, note that policies could be such as to avoid the dependence on history. A policy change could shift the after-tax marginal product curve entirely above the sum of labor gromh, depreciation, and discount ratea, leading to sustained growh regandless of initial conditions.
} 
The subsistence equilibrium will be stable if the first term in brackets in (6) is negative, i.e. if the net marginal product of capital is less than the discount rate plus the adjusted labor growth rate, evaluated at the subsistence capital stock $\mathrm{k}_{\mathbf{2}}$ :

$$
(1-\tau) A \gamma\left(\gamma+(1-\gamma) k_{s}^{-\epsilon}\right)^{\frac{1-\epsilon}{\epsilon}}-((1-\beta) \eta+\delta+\rho)<0
$$

If (8) holds, then at subsistence the consumer will not find it worthwhile to accumulate more capital (point $\mathrm{A}$ in figure 2). ${ }^{15} \mathrm{~A}$ higher tax rate will make it more likely that (8) holds, both because it lowers the first term directly, and because it increases the subsistence capital stock $k_{2}$. Similarly, higher labor growth, higher depreciation of capital, and a higher discount rate will all make it more likely that (8) holds, i.e. that the economy will be stuck at subsistence.

If (8) is violated at the subsistence level $k_{\mathfrak{v}}$, then the consumer will want to accumulate more capital until the net marginal product falls to equality with the discount rate plus the rate of labor growth (i.e. till (8) holds with equality such as point $B$ for a capital level above $k$, in figure 2). This will be the modified golden rule equilibrium of the Solow-Cass model. Note that this equilibrium will only be feasible if it yields a value of consumption above subsistence. Thus, another interpretation of (8) is that it gives the condition for the subsistence capital stock to lie above the modified golden rule capital stock. Whichever capital stock is greater will be the stable equilibrium.

${ }^{2}$ This result mirrors that of Rebelo (1991b). 
Figure 2

Net marginal product of capital and alternative steady states

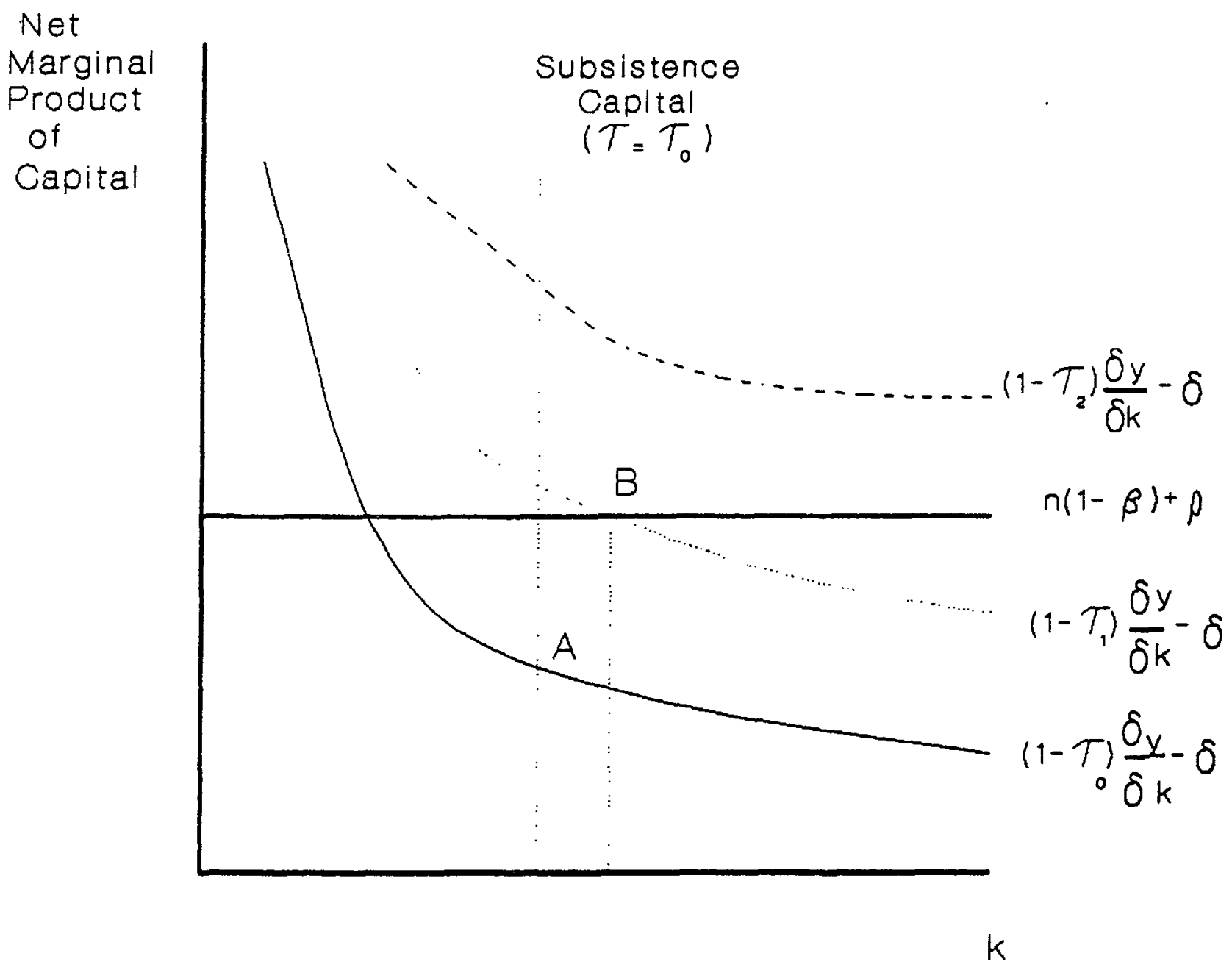


However, it is not assured that there is any capital stock sufficiently large to equate the net marginal product to the discount rate plus labor growth. Recall from (2) that the marginal product of capital approaches a positive minimum as the capital labor ratio goes to infinity. If this minimum, net of depreciation, lies above the discount rate plus labor growth, then no stable fixed income equilibria will exist:

$$
\frac{(1-\tau) A \gamma^{\frac{1}{\epsilon}}-((1-\beta) \eta+\delta+\rho)}{\sigma}>0
$$

If (9) holds, then the consumer will find it worthwhile to increase capital indefinitely (see $\tau_{2}$ curve in figure 2). In the limit, per capita growth will approach the expression given in (9).

From (9), we see that stagnation is more likely with higher taxes, higher labor growth, higher depreciation, and a higher discount rate. ${ }^{16}$ If there is growth, the same factors make growth lower. (However, note that if $\beta=1$, labor growth will have no effect on whether per capita growth takes place.) Combining this result with the previous one, we see policy continuity -- as the tax rate rises, it lowers the rate of growth, until finally growth stops all together. Further increases in the tax rate lower the fixed level of income until income falls to subsistence. A range of tax rates will be consistent with subsistence. ${ }^{17}$

Figure 3 shows the conventional Cass-Koopmans phase diagrams for the subsistence and modified golden rule equilibrium. Multiple steady states exist, but only one steady state at a time exhibits saddle-point stability.

\footnotetext{
${ }^{16}$ A similar result is noted in Jones and Manuelli (1990).

${ }^{17}$ From (8) and (9) it is apparent that changes in $A$ are equivalent to changes in $r$ of oppōsite sign. This implies that a permanent one-time exogenous technological thift can be sufficient to escape a subsistence income trap, or to move from zero per capita growh to positive growth. This gives an interesting contrast to the traditional neoclassical modet in which continuous technological progress is required for per capica growh. Similarty, a negative shock (like a civil war) could induce stagnation in a previousty growing connomy.
} 
The transitional properties of this model are also interesting. From (6), we can see that two offsetting factors will be at work in determining the speed of growth during a transition from stagnation to growth. A country with an initially low per capita capital stock will have a high before-tax marginal product of capital and would grow rapidly, just as in the Solow model. However, this is offset by the low saving propensity at low income levels, as reflected in the second term in (6). Simulations of the saddle path of the model reveal a "hump-shaped" pattern of accelerating then decelerating growth as shown in figure $4 .^{18}$ This property of the nodel offers a possible explanation of the rapid growth of middle-income countries compa. * o very poor and very rich countries.

\section{Extensions of the Model}

A model with multiple inputs is relevant to analyze policies which distort the allocation of resources among different activities, policies that are common in developing countries. This extension will also be useful to examine the role played by public sector capital.

\footnotetext{
${ }^{18}$ Accelerating growh (but not decelerating) during the transition is noted in the Rebelo (1991) application of a Stone-Geary utility function. A "hump-shaped" relationship between transitional growh and per capita income is oberved in the analyzis of King and Rebelo (1990) of the transitional dynamics of the Solow model with Stone-Geary utility, for exactly the same reason as in this paper. "Hump-shaped" tranaition path also follow from technology adoption models because of the well-known logintic curve for new product Output (Joranovic and Lach (19\%1), Wan (1990)).
} 
$19 a$

Figure 3

Subsistence and modified golden rule equilibria

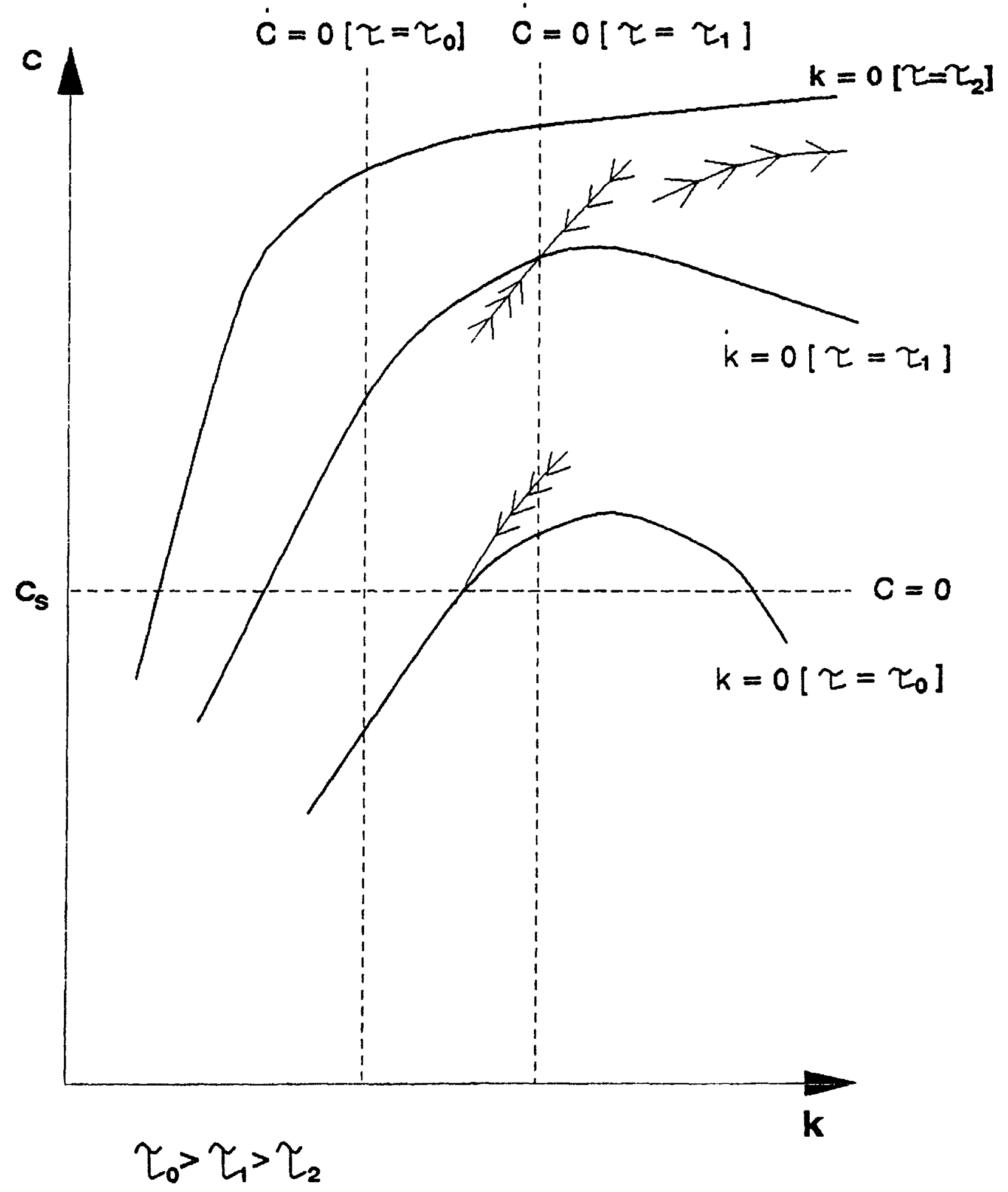




\section{Growth during the transition to the steady state}

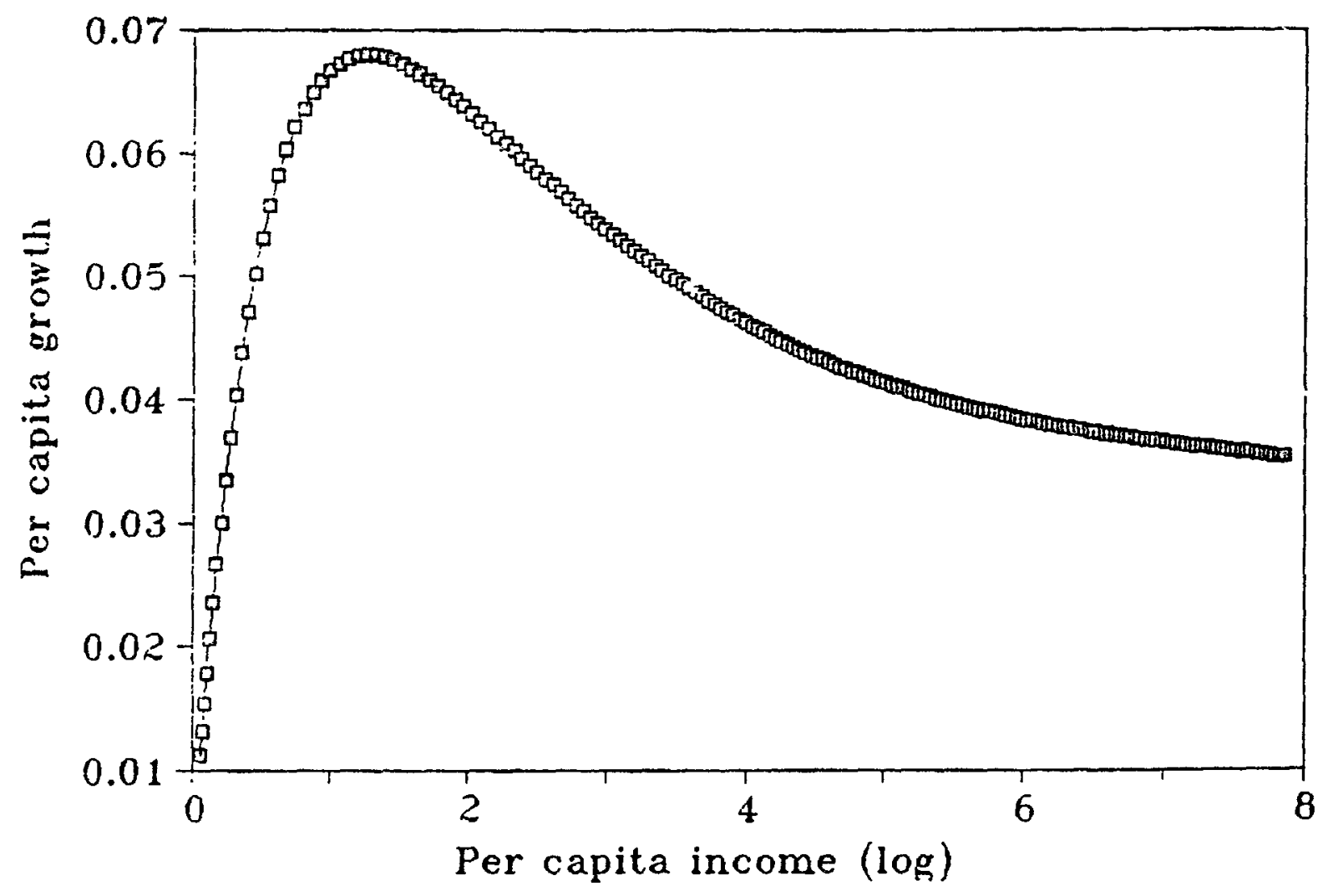




\section{a. Multiple inputs with distortionary policies}

We extend the production function to include two generic types of capital, $K_{1}$ and $K_{2}$, with elasticity of substitution $1 /(\Theta-1)$. Capital and labor continue to have elasticity of substitution $1 /(\epsilon-1)$ (which is still assumed to be greater than one in absolute value):

$$
Y=A\left[\gamma\left[\alpha R_{1}^{\theta}+(1-\alpha) R_{2}^{\theta}\right]^{\frac{\epsilon}{\theta}}+(1-\gamma) L^{\epsilon}\right] \frac{1}{\epsilon}
$$

We assume the consumer-producer still maximizes (3). The equations of accumulation of the two types of capital in per capita terms are:

$$
k_{1}=1_{1}-(\delta+\eta) k_{1}
$$

$$
k_{2}=1_{2}-(\delta+\eta) k_{2}
$$

The type of distortionary policy that we consider will be a sales tax that falls on investment purchases of type 1 , with type 2 investment exempted or able to evade the tax. Easterly, King, Levine, and Rebelo (1990) show how this type of structure can be applied to many types of distortionary policies in developing countries, including sales taxes that are evaded by the underground economy, import tariffs and quotas, administrative credit allocation, black market premia in dual foreign exchange markets, and inflation taxes that fall on the monetized sector but are avoided by the non-monetized sector. ${ }^{19}$

\footnotetext{
${ }^{19} \mathrm{~A}$ sales tax on investment type 1 is also equivaicnt to a tax on the income from capital type 1 . The income tax equivalent to a sales tax $t$ is $t /(1+t)$. The proceeds of the tax are assumed to te nonproductively dissipated.
} 
Per capita consumption must obey the household's per capita budget constraint:

$$
c=A\left[\underline{\gamma}\left[\alpha k_{1}^{\theta}+(1-\alpha) k_{2}^{\theta}\right]^{\frac{\epsilon}{\theta}}+1-y\right]^{\frac{1}{\epsilon}} \cdot(1+\tau) 1_{1}-1_{2}
$$

where $\tau$ is the rate of sales tax on type 1 investment. The first order conditions for maximizing (3) imply that the ratio of marginal products of type 1 to type 2 capital is equal to $1+\tau$, which implies the following ratio of the type 2 to type 1 of capital, denoted $\Phi$ :

$$
\Phi=\frac{k_{2}}{k_{1}}=\left[\frac{(1-\alpha)(1+r)}{\alpha}\right]^{\frac{1}{1-\theta}}
$$

The growth in per capita consumption along the optimal path will be given by:

$$
g=\left[\frac{r_{2}-((1-\beta) \eta+\delta+\rho)}{\sigma}\right]\left[\frac{c-c_{s}}{c}\right]
$$

where $r_{2}$ is the derivative of per capita output with respect to the per capita stock of type 2 capital. This in turn will be given by:

$$
r_{2}=\operatorname{Ar}(1-\alpha)\left[\gamma\left(\alpha \Phi^{-\theta}+1-\alpha\right)^{\frac{\epsilon}{\theta}}+(1-\gamma) k_{2}^{-\epsilon}\right]^{\frac{1}{\epsilon}-1}\left(\alpha \Phi^{-\theta}+1-\alpha\right)^{\frac{\epsilon}{\theta}-1}
$$

As before, if $\epsilon>0$ (elasticity of substitution between capital and labor greater than one in absolute value), the marginal product of capital will go to a nonzero limit as both capital-labor ratios go to infinity (recall the ratio $\Phi$ is given by (14)). Specifically, we have:

$$
\lim _{k_{2}+\infty} r_{2}=A \gamma^{\frac{1}{\epsilon}}(1-\alpha)\left(\alpha \Phi^{-\theta}+1-\alpha\right)^{\frac{1-\theta}{\theta}}
$$


If this limit is grearer than the sum of the discount rate, depreciation rate, and labor growth, then positive per capita growth will ensue at the asymptotic rate:

$$
g=\frac{A \gamma^{\frac{1}{\epsilon}}(1-\alpha)\left(\alpha \Phi^{-\theta}+1-\alpha\right)^{\frac{1-\theta}{\theta}}-(\delta+(1-\beta) \eta+\rho)}{\sigma}
$$

In other words, per capita growth will take place if the right-hand side of (18) is positive. If (18) is negative, per capita output will stagnate and the capital-labor ratio will be such as to satisfy the modified golden rule. From (14) and (18), it can be seen that distortionary policies tend to make stagnation more likely. ${ }^{30}$ An increase in the distortionary $\operatorname{tax} \tau$ will increase the ratio of type 2 to type 1 capital (14) above the socially optimal level. This could lower the asymptotic marginal product of type 2 capital (17) sufficiently that (18) becomes negative and growth stops. Further tax increases can cause a regression toward subsistence income, just as in the previous section.

\section{b. Public capital and growth}

The model of the previnus section can also be used to discuss the effect of public capital on growth. It is plausible that there are capital inputs that can only be provided by the public sector. We consider public capital inputs that will not be forthcoming in a competitive market system (say because of technological difficulties in charging per unit of use), but otherwise satisfy the usual properties of private goods (rivalry in consumption, perfect divisibility, diminishing marginal product, etc.).

Equation (10) can then be used to cover the case of public and private capital. Government "capital investment" includes all activities that contribute to human or physical

\footnotetext{
20 This is in contras to the argument that distortionary policies only have level effects, as argued by Lucas (1988) and Young (1991). A micro-besed model with effects of distortionary policies on growth is Murphy, Shleifer and Vishny (1991.
} 
capital, such as education, highways, basic health measures, or electrical distribution. $K_{1}$ is interpreted as a government capital input, and $\mathrm{K}_{2}$ is interpreted as private capital. We assume that the government finances the construction of public capital with lump-sum taxes (taxes which do not affect growth). The government is assumed to follow a policy rule where the ratio of public to private capital is maintained constant over time. $\tau$ in equation (14) can be interpreted as a measure of the ex-post distortion induced by supplying too little (positive $\tau$ ) or too much (negative $\tau$ ) public capital.

Equation (18) now gives the asymptotic growth rate determined by private sector investment in type 2 capital. If (18) is negative, output will stagnate. We see that output is more likely to stagnate the lower is the ratio of public to private capital (i.e. the higher is the ratio of type 2 to type 1 capital $\Phi$ ). The reason is simple: lower public capital lowers the asymptotic rate of return to private capital, possibly below the critical value given by the sum of the depreciation. population growth, and discount rates. Since growth is determined by the private return to capital, higher public capital always increases the likelihood of growth, even if it is suboptimal from the standpoint of total welfare. ${ }^{2 t}$

\section{Empirical evidence}

The model makes several predictions: (1) countries that penalize capital or distort its allocation are more likely to stagnate (and such policies will cause lower growth if a country is growing); (2) initial income does not affect whether countries stagnate; (3) countries that do grow will follow a hump-shaped transition path where growth rises and then falls with rising income.

\footnotetext{
${ }^{21}$ An obvious extenaion is to consider public capital spending financed by a tax that affects growh. This was considered for more general growth models in Barro (1990) Barro and Sala-i-Martin (1990), and Easterty (1990b), and is not directly considered here-
} 
These predictions differ from those of other endogenous growth models underlying recent work on growth (e.g. Barro (1991)), in that right-hand side variables do not affect growth continuously. The model suggests that countries can be in one of two regimes -- either sustained growth, where right-hand side variables have growth effects, or stagnation, when a function of right-hand side variables passes a threshold level. The determination of stagnation involves steadystate factors -- forward-looking consumer-producers decide on the basis of preference, production, and policy parameters whether steady-state growth is worthwhile. ${ }^{22}$ The growth of growing countries. on the other hand, includes transitional dynamus such as the aforementioned humpshaped relationship between growth and initial income. Policy variables also could have transitional effects on growth that differ from their effects on the stagnation/growth outcome.

This formulation suggests the use of limited dependent variable methods to take into account the truncation of growth rates induced by stagnation. A probit equation will be specified to predict whether countries stagnate. A truncated regression will predict the growth rate of growing countries. Under a null hypothesis of the conventional continuous model, both methods would still yield consistent estimators of the effect of right-hand side variables on growth. The continuous model in effect imposes the restriction that the coefficients are the same in the two equations. ${ }^{23}$ This implication can be tested by nesting the probit and truncated regressions within a tobit equation (which also yields consistent estimators of the continuous model under the null hypothesis) and constructing a likelihood ratio statistic for equality of coefficients between the probit and truncated equations. ${ }^{24}$ If equality of coefficients were rejected, the continuous model

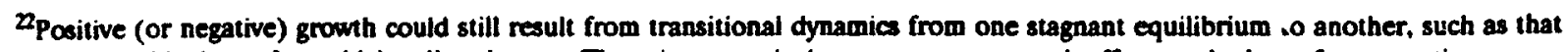
due to a favorable (or unfavorable) policy change. There is no a priori reason to expect such effects to be large for stagnating countries.

${ }^{23}$ Adjusted for the standand error, since the probit is based on the standard normal distribution.

${ }^{24}$ Greene (1990) has a lucid description of this procedure. Note the "equality of coefficients" must be evaluated with probit cofticients (based on the standand normal) adjusted for the size of the standard crror.
} 
would be shown to be inappropriate and the prediction of different regimes for growth and stagnation would be confirmed.

The empirical problem is to de. Tne stagnation. The approach taken here is to define a country as stagnating when its growth rate is below 0.1 percent. All countries with negative growth are presumed to be in a transition towards a lower fixed-income equilibrium. In the tobit equation, for example, the dependent variable will be defined as zero for all observations that satisfy this definition of stagnation, while the actual per capita growth will form the dependent variable in the non-stagnating cases. ${ }^{25}$

The set of right-hand side variables indicated by the model include (1) implicit or explicit taxes on capital (section II.1), (2) variables reflecting policy distortions of resource allocation (section II.2.a), and (3) variables that reflect government physical and human capital spending (section II.2.b). Labor growth and per capita income will also enter as explained earlier. The equations are estimated alternatively with all variables defined as 10 -year averages (table 4) and 30-year averages (table 5), except for per capita income, which is given as income in the first year of the period. We also show in the table the probit coefficients adjusted by the standard error to be comparable to the tobit and truncated coefficients.

One set of variables common to other empirical growth work that is not used here are investment ratios and measures of human capital like primary and secondary enrollment ratios. Since the model relies on a definition of capital that includes unobservable components like training and knowledge, it seems best to estimate reduced forms that do not rely on measuring

\footnotetext{
${ }^{25}$ This procedure is equivalent to discarding the information contained in differences among negative growth observations. As argued before, this does not bias the estimates even if the true model is continuous. The sample is endogenousty truncated, and the limited dependent variable methods then correct for the truncation. This roundabout prodecure allows us to teat the implication of regime change with eeparate probit and truncated regreasions.
} 
capital accumulation. Only exogenous variables (policy and other) will be included in these regressions. $^{26}$ The results obtained are as follows: ${ }^{27}$

Likelihood ratio tests. The restriction that coefficients are the same across probit and truncated regressions is rejected in five out of the six regressions using decade averages (Table 4). It is notable that the coefficients on per capita income (and income squared) are insignificant in the probit equation but significant in the truncated equation. These results support the prediction that initial income does not affect whether a country stagnates or not but does affect the growth rate if it grows. ${ }^{28}$

In the regressions with 30-year averages (Table 5), the restriction is not rejected. It makes sense that the restriction is more likely to be rejected with 10 -year averages but not with 30-year averages, since one would expect transitional effects to be stronger with the former. However, one would have expected transitional effects to still be important with 30-year growth rates.

Initial per capita income. The hump-shaped relation between income and growth is confirmed by 5 out of the 6 regressions using decade averages (Table 4), as both income and income squared are significant with the predicted signs in the truncated regressions. ${ }^{29}$ The maximum of the hump varies between $\$ 900$ and $\$ 1800$ in 1985 prices. This contrasts to the negative linear effect of per capita income on growth found by, among others, Balassa (1985),

\footnotetext{
${ }^{26}$ Some regressions were run with the total investment ratio on the right-hand side to comine whether it crucially affects the results. The interpretation of such equation would be that stagnation would occur either because investment was too low or because other variables lowered the efficiency of investment. Inveatment was generally significant and the results were otherwise similar to those reported here. However, these regreations are problematic because imveatment is preaumably endogenous, which is difficult to addres in the limited dependent variable context.

${ }^{27}$ For the citations of previous results, I was aseinted greatly by the survey of Renelt (1991).

${ }^{23}$ When the sample is restricted to developing countries, equality of coefricients is rejected in 3 out of the 6 regressions. The weaker result is not surprising in view of the narrower range of the per capita income variable in this case.

${ }^{20}$ Again, the results are weaker if the sample is limited to developing countrien, with only 1 out of the 6 truncated regreasions showing significant coeficients on income and income squred.
} 
Barro (1991), Fischer (1991), Grier and Tullock (1989), Landau (1986), and Murphy, Shleifer, and Vishny (1991)..$^{30}$ A quadratic term was found to be marginally significant by Barro (1991), but with the opposite sign from that found here.

No effect of per capita income on growth is detected in the regressions with 30 -year averages for all variables (except initial income) in Table 5. Again, it is not surprising that transitional effects are weaker with 30 -year averages. ${ }^{31}$

The black market exchange rate premium. This is a widely available measure of price distortion, reflecting an implicit tax on producers of traded goods that are priced according to the official exchange rate. For example, it is a tax on exporters that are forced to deliver foreign exchange at the official rate, rather than the black market rate. We assume the proceeds of the "tax" are dissipated. An increase in the black market premium should than make stagnation more likely. Levine and Renelt (1990) and Easterly (1990b) found this variable to be insignificant in cross-section regressions. ${ }^{32}$

By contrast, the black market premium is found to be consistently significant here, no matter what other right-hand side variables are included. The significance of the probit and truncated coefficients varies -- with 30 -year averages, it is the probit that is consistently significant, while with 10 -year averages, both are generally significant. We conclude that the black market

\footnotetext{
${ }^{30}$ However, Michael Kremer reports finding the "hump-shaped" pattem predicted here in unpublished results.

${ }^{31}$ Although again the lack of significance with 30-year averages is disconcerting, since simulations seem to indicate that transitional dynamics in the Jones-Manuelli model can be quite prolonged.

${ }^{32}$ However, other measures of price distortions have been found to be significant in the literature. Barro (1991) reports that the abeolute value of deviations of the relative price of investment goods is significantly negative in a cross-country growh regreasion. De Long and Summers (1991) found that a high relative price of equipment investment goods has a negative effect on growth. De Long and Summer (1991) and Easterly (1990a) found a dummy variable measuring outward trade orientation from the 1987 World Development Report to have a positive and significant effect on growh. Dollar (1990) found a measure of general overvaluation of real exchange rates, based on Summers-Heston relative price data, to lower growh.
} 
premium is a good predictor both of whether countries stagnate, and how fast they grow if they do not stagnate.

Public investment as a share of GDP. The theory predicts that higher public investment (measured conventionally as physical investment only) makes stagnation less likely. This variable is only available for the 1970's and 80 's, and only for a reduced sample of countries. (For this reason, this variable was omitted from the regressions with 30-year averages). Other studies, such as Barro (1991) and Khan and Reinhart (1990), have generally found this variable to be insignificant in growth regressions.

The regressions with decennial averages show some evidence that higher public investment makes stagnation less likely. ${ }^{33}$ Public investment is positive and significant at 5 percent in one probit regression and at 10 percent in another. However, we also find the puzzling and significant result that higher public investment causes growth to be lower in the truncated regressions. This surprising finding is inconsistent with theoretical predictions and merits further investigation.

Government consumption. The share of government consumption in GDP is found to have a significant effect on growth in studies such as Barro $(1990,1991)$, Romer $(1989 a)$, and Easterly (1990b). In terms of this model, government consumption can be seen a proxy for the part of the tax burden not offset by productive spending. Thus, an increase in government consumption should make stagnation more likely. We find no evidence for such an effect, however, as government consumption is only significant at the 10 percent level in one regression, and of the wrong sign.

\footnotetext{
${ }^{33}$ No regressions were run including public investment for the 30-year average, because the sample size was too small for the use of noniinear econometric techniquea.
} 
Government expenditure on education. This measures one form of productive government investment. Higher education spending should make stagnation less likely. This variable was found to have an insignificant effect on growth in Diamond (1990). In contrast, we find some evidence here that government spending on education influences stagnation and growth, as it is significant in the tobit and truncated regressions for 30-year averages, and in one of the tobit and probit equations for decennial averages. The significance is not robust, as it vanishes when variables like government consumption are added.

Labor force growth. The model predicts that population or labor growth has a zero or negative effect on growth, depending on whether the parameter $\beta$ is equal to or less than one, respectively. If it is one, then consumers place a value on the number of their descendants that exactly offsets the negative effect of having to spread future capital around more people. Thus, higher labor growth will either make stagnation more likely or will have no effect. Mixed results for the effects of labor growth on per capita growth have been reported in the literature: Barro found it to be significantly negative, Grier and Tullock (1989) positive, and Balassa (1985), De Long and Summers (1990), Landau (1986) and Mankiw, Romer and Weil (1990) insignificant. The results here include some weak evidence for high labor growth making stagnation more likely. The coefficient on labor in probit equations is significant at 5 percent in one instance, but the coefficient reverses sign in other specifications.

Inflation. Inflation represents a tax on investment to the extent that cash must be held in advance of investment transactions. Higher inflation will make stagnation more likely if these cash-in-advance requirements are significant. Inflation was found to be significantly negative in growth regressions in Grier and Tullock (1989) and Fischer (1991). The results here show some evidence that inflation makes stagnation more likely, as the coefficient is significant and negative in one of the truncated regressions (regression $v$ in table 4). The coefficient on 
inflation in the probit equation with the same set of variables is not significant. Even the significance of the inflation coefficient in the probit regression vanishes in other specifications.

Financial repression dummy. Controls on interest rates such that real interest rates in the financial system are highly negative will lead to allocation of credit by administrative fiat. This imposes a tax on investment by those who do not have access to subsidized credits; we presume the subsidized crecits themselves to flow to nonproductive uses. This variable is defined as 1 if the average real deposit interest rate over the period is less than -5 percent and 0 if it is greater. A value of 1 makes stagnation more likely. This variable was found to be significant in Gelb (1990), Easterly (1990b), and Roubini and Sala-i-Martin (1991). However, we fail to find any evidence for financial repression affecting growth or stagnation in these results. The main effect of including this variable is to render insignificant per capita income and the likelihood ratio test statistic.

Time and continent dummies. The model considers only national policies as affecting growth, but it is plausible that there are also global influences (the well-known slowdown in world growth in the 80 's for example). The regressions control for these influences by putting one dummy variable each for the decades of the 60's and 70's. We also consider continent dummies that other studies have found to be significant.

The dummies for Latin America and Africa are generally significant in these results, as they have been in most other studies (e.g. Barro (1991)). This suggests there are other factors influencing growth and stagnation that have not been captured here. The time dummies are also generally significant in both probit and truncated regressions, which could be indicating some exogenous worldwide productivity trends. ${ }^{34}$

\footnotetext{
34 The model of section 11 could be modified to incorporate exogenous productivity growth. Stagnation would then be defined as growth equal to the exogenous productivity trend. The result here indicates that stagnation (defined as zero growth and below) became unore likely in the $1980 \mathrm{~s}$, which could be interpreted as a decrease in exogenous productivity grownh.
} 


\section{Conclusion}

Stagnation due to the presence of fixed factors is consistent with an array of statistical evidence. Economic policies, and not initial conditions, determine whether countries stagnate. The black market premium on foreign exchange is particularly helpful in expiaining stagnation. Empirical results show that growth first accelerates and then falls as income rises. Results confirm that initial income and policy variables have a different effect on whether a country stagnates than they do on the rate of growth once it starts growing, as expected from the distinction between steady state and transitional effects. These results suggest that cross-section growth regressions may be misspecified because of the nonlinearity inherent in the possibility of steady-state stagnation. 
Tuble 4

Tobia, Probih, and Trunculod regreniva revulas, regresioca by decoules

(r.Stuinica in parcalbecos)

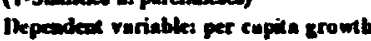

\begin{tabular}{|c|c|c|c|c|c|c|c|c|c|c|c|c|c|c|c|c|c|c|c|}
\hline & & Cunation & $\begin{array}{l}\text { Exituance } \\
\text { Recte } \\
\text { Prentium }\end{array}$ & ion & $\begin{array}{l}\text { Public } \\
\text { Invereme } \\
\text { ohare of } \\
\text { GDP }\end{array}$ & $\begin{array}{l}\text { Gov'1 } \\
\text { expend. } \\
\text { on oduc } \\
\text { ghare GDP }\end{array}$ & $\begin{array}{l}\text { Initiol } \\
\text { level } \\
\text { of inc } \\
\text { per cap }\end{array}$ & $\begin{array}{l}\text { Square of } \\
\text { Initial lev } \\
\text { of ine } \\
\text { per cap }\end{array}$ & $\begin{array}{l}\text { Covi'i } \\
\text { compump. } \\
\text { ithere of } \\
\text { GIDP }\end{array}$ & $\begin{array}{l}\text { I mbor force } \\
\text { erowith }\end{array}$ & $\begin{array}{l}\text { Itumen } \\
\text { cial } \\
\text { Dummy }\end{array}$ & $\begin{array}{l}\text { Iime } \\
\text { durmmy } \\
19006\end{array}$ & $\begin{array}{l}\text { Tume } \\
\text { durnmy } \\
1970 .\end{array}$ & Alein & $\begin{array}{l}\text { Africion } \\
\text { dunomy }\end{array}$ & $\begin{array}{l}\text { Imlin } \\
\text { Americk } \\
\text { dumeny }\end{array}$ & $\begin{array}{l}\text { Sumple } \\
\text { Size }\end{array}$ & $\begin{array}{c}\text { Liketibood" } \\
\text { ntio } \\
\text { lene }\end{array}$ & $\begin{array}{l}\text { Meximosen } \\
\text { poind w. r.t. } \\
\text { per capina } \\
\text { imoone }\end{array}$ \\
\hline \multirow[t]{4}{*}{ i. } & Tobix & $\begin{array}{c}-0.17 \cdot \\
(-1.66)\end{array}$ & $\underset{(-0.22)}{-0.03 * \cdots *}$ & $\begin{array}{r}-0.005 \\
(-0.297)\end{array}$ & & & $\begin{array}{l}0.054 \cdots \\
(2.004)\end{array}$ & $\begin{array}{l}-0.004 \\
(-2.08)\end{array}$ & $\begin{array}{c}-0.01 \\
(-0.27)\end{array}$ & $\begin{array}{l}.00013 \\
(-0.74)\end{array}$ & & $\begin{array}{l}0.019 \cdots 0 \\
(5.109)\end{array}$ & $\begin{array}{l}0.017000 \\
(5.31)\end{array}$ & $\begin{array}{r}0.006 \\
(1.18)\end{array}$ & $\begin{array}{l}-0.016 \cdots 0 \\
(-3.21)\end{array}$ & $\begin{array}{l}-0.017 \\
(-3.09)\end{array}$ & 210 & 24.2400 & 1429 \\
\hline & Probie & $\begin{array}{l}0.87 \\
(0.095)\end{array}$ & $\begin{array}{l}-1.79 \cdot 00 \\
(-3.44)\end{array}$ & $\begin{array}{r}0.015 \\
(0.02)\end{array}$ & & & $\begin{array}{c}0.420 \\
(0.17)\end{array}$ & $\begin{array}{r}-0.031 \\
(-0.18)\end{array}$ & $\begin{array}{c}-0.56 \\
(-0.15)\end{array}$ & $\begin{array}{l}-0.34^{\circ} \\
(-1.88)\end{array}$ & & $\begin{array}{l}1.37 \cdots \\
(364)\end{array}$ & $\begin{array}{l}1.19 \cdots \cdots \\
(3.85)\end{array}$ & $\begin{array}{r}0.211 \\
(029 n)\end{array}$ & $\begin{array}{l}-1.29 \cdot 0 \\
(-2.36)\end{array}$ & $\begin{array}{l}-1.42 \cdots \cdots \\
(-2.79)\end{array}$ & 210 & & 933 \\
\hline & Mdj. Prob. & 0.03 & $-0.03 \cdots$ & 0.0002 & & & 0.006 & -0.0005 & -0.01 & -0.005 & & $0.02 \cdots$ & $0.02 \ldots$ & 0.003 & -0.02 & $-0.02 \cdots \cdots$ & & & \\
\hline & Truaculod & $\begin{array}{l}-0.36 \cdots 0 \\
(-2.95)\end{array}$ & $\begin{array}{c}-0.024 \\
(-2.099)\end{array}$ & $\begin{array}{r}-0.022 \\
(-1.12)\end{array}$ & & & $\begin{array}{l}0.106 * \cdots \\
(3.21)\end{array}$ & $\begin{array}{l}-0.007 \\
(-3.25)\end{array}$ & $\begin{array}{l}0.005 \\
(0.13)\end{array}$ & $\begin{array}{l}0.0002 \\
(0.12)\end{array}$ & & $\begin{array}{l}0012 \bullet \cdots \\
(2.78)\end{array}$ & $\begin{array}{l}0.012 \cdots \cdots \\
(2.99)\end{array}$ & $\begin{array}{r}0.005 \\
(0.99)\end{array}$ & $\begin{array}{l}.0 .011^{\circ} \\
(-1.99)^{2}\end{array}$ & $\begin{array}{l}-0.01 \cdots \\
(-2.16)\end{array}$ & 162 & & 1830 \\
\hline \multirow[t]{4}{*}{ ii. } & Tobit & $\begin{array}{c}0.076 \\
(0.58)\end{array}$ & $\begin{array}{l}-0.033 \cdots \\
(-2.07)\end{array}$ & & & & $\begin{array}{c}-0.0102 \\
(-0.31)\end{array}$ & $\begin{array}{l}0.0005 \\
(0.24)\end{array}$ & $\begin{array}{c}-0.06 \\
(-1.08)\end{array}$ & & $\begin{array}{r}-0.003 \\
(-0.55)\end{array}$ & $\begin{array}{l}0.023 \cdots \\
(5.26)\end{array}$ & $\begin{array}{l}0019 \\
(4.21)\end{array}$ & $\begin{array}{r}0007 \\
(1.14)\end{array}$ & $\begin{array}{l}-0.021 \cdots 0 \\
(-3.006)\end{array}$ & $\begin{array}{c}-0.011 \\
(-1.94)\end{array}$ & 116 & 15.57 & $21765^{\prime}$ \\
\hline & Probici & $\begin{array}{l}19.23 \\
10.07)\end{array}$ & $\begin{array}{l}-260 \cdots \\
(-2.38)\end{array}$ & & & & $\begin{array}{r}-3.287 \\
(-0.61)\end{array}$ & $\begin{array}{r}0.203 \\
(0.55)\end{array}$ & $\begin{array}{c}-4.33 \\
(-0.54)\end{array}$ & & $\begin{array}{c}-047 \\
(-0.65)\end{array}$ & $\begin{array}{l}2.51 \cdots \cdots \\
(3.27)\end{array}$ & $\begin{array}{l}2.38 \cdots \\
(2.99)\end{array}$ & $\begin{array}{c}-152 \\
(-0.016)\end{array}$ & $\begin{array}{c}-6.93 \\
(-0.025)\end{array}$ & $\begin{array}{l}-6.03 \\
(-0.022)\end{array}$ & 116 & & $3250^{\prime}$ \\
\hline & Adj. Prob. & 0.30 & -0.0400 & & & & -0.049 & 0.003 & -0.06 & & -0.01 & $0.04 * \cdots$ & $0.04 \ldots$ & .0 .07 & -0.10 & -0.09 & & & \\
\hline & Trunculod & $\begin{array}{c}-0.02 \\
(-0.099)\end{array}$ & $\frac{-0.030^{\circ}}{(-1.67)}$ & & & & $\begin{array}{c}0.014 \\
(0.304)\end{array}$ & $\begin{array}{r}-0.001 \\
(-0.36)\end{array}$ & $\begin{array}{r}-0.044 \\
(-0.66)\end{array}$ & & $\begin{array}{r}-0.001 \\
(-0.15)\end{array}$ & $\begin{array}{l}0.019 \text { (3.00 } \\
(3.298)\end{array}$ & $\begin{array}{l}0.016 \\
(2.69)\end{array}$ & $\begin{array}{c}001 \\
(1.62)\end{array}$ & $\begin{array}{l}-0.014 \cdot \\
(-1.61)\end{array}$ & $\begin{array}{r}-0.005 \\
(-0.73)\end{array}$ & 95 & & 759 \\
\hline \multirow[t]{4}{*}{ iii. } & Tobin & $\begin{array}{c}-0.12 \\
(-1.23)\end{array}$ & $(-4.898)$ & & & $\begin{array}{l}0.24 \text { "*. } \\
(2.24)\end{array}$ & $\begin{array}{l}0.0401 \\
\text { (1.57) }\end{array}$ & $\underset{(-1.7)}{-0.003}$ & & & & $\begin{array}{l}0.026 \cdots 0 \\
(6.26)\end{array}$ & $\begin{array}{l}0.019 \\
(5.87)\end{array}$ & $\begin{array}{c}0.008 \\
(1.56)\end{array}$ & $\begin{array}{l}-0.015 \cdot 0 \times 1 \\
(-2.75)\end{array}$ & $\frac{-0.014}{(-2.096)}$ & 177 & $20.45 \circ$ & 860 \\
\hline & Probit & $\begin{array}{l}12.76 \\
(1.09)\end{array}$ & $\begin{array}{l}-2.16 \cdots * \\
(-3.7)\end{array}$ & & & $\begin{array}{l}20.62 \cdots \\
(2.08)\end{array}$ & $\begin{array}{r}-2.844 \\
(-0.89)\end{array}$ & $\begin{array}{r}0.172 \\
(0.80)\end{array}$ & & & & $\begin{array}{l}2.21 \cdots \\
(4.44)\end{array}$ & $\begin{array}{c}1.660000 \\
(4.49)\end{array}$ & $\begin{array}{c}-0.15 \\
(-0.15)\end{array}$ & $\begin{array}{l}-2.28 \\
(-2.58)\end{array}$ & $\begin{array}{c}1.9600 \\
(-2.48)\end{array}$ & 17 & & $3847^{2}$ \\
\hline & Adj. Prob. & 0.20 & $-0.03+\cdots$ & & & $0.33 \cdots$ & -0.045 & 0.003 & & & & $0.04 \cdots$ & 0.03 & .0 .002 & $-0.04 \times \infty$ & $-0.03 \star \bullet$ & & & \\
\hline & Truncaled & $(-2.46)$ & $\begin{array}{l}-0.03 \cdots \cdots \\
(-2.82)\end{array}$ & & & $\begin{array}{l}0.205= \\
(1.74)\end{array}$ & $\begin{array}{l}0.084 \cdots 0 \\
(2.81)\end{array}$ & $\begin{array}{l}-0.006 \\
(-2.97)\end{array}$ & & & & $\begin{array}{l}0.02 \cdots \\
(387)\end{array}$ & $\begin{array}{l}0015=00 \\
\text { (3.38) }\end{array}$ & $\begin{array}{c}0.01 \\
(1.56)\end{array}$ & $\begin{array}{c}-0.01 \\
(-1.37)\end{array}$ & $\begin{array}{c}-0.01 \\
(-1.77)\end{array}$ & 137 & & 1385 \\
\hline \multirow[t]{4}{*}{ iv. } & Tobii & $\begin{array}{r}0.013 \\
(0.08)\end{array}$ & $\begin{array}{l}-0.05 \cdots 0 \\
(-7.85)\end{array}$ & & $\begin{array}{r}-0.024 \\
(-0.20)\end{array}$ & & $\begin{array}{c}0.008 \\
(0.1 \%)\end{array}$ & $\begin{array}{c}-0.001 \\
(-0.303)\end{array}$ & & & & & $\begin{array}{l}0.013 \cdot 0 * \bullet \\
(2.71)\end{array}$ & & & & 96 & 4231004 & - 157 \\
\hline & Probih & $\begin{array}{l}61.822^{\circ *} \\
(2.53)\end{array}$ & $\begin{array}{l}-5.08000 \\
(-3.35)\end{array}$ & & $\begin{array}{l}17.98 \\
(1.59)\end{array}$ & & $\begin{array}{l}-16.195 \\
(-2.52)\end{array}$ & $\begin{array}{l}1.052 \cdots \\
(2.51)\end{array}$ & & & & & $\begin{array}{l}645 \cdots \\
(2.81)\end{array}$ & & & & 96 & & $2200^{2}$ \\
\hline & Adj. Prob. & 0.91 & -0.090 .0 & & 0.26 & & $-0.238 \propto \bullet$ & $0.015 *$ & & & & & $0095 \ldots$ & & & & & & \\
\hline & Trunesuled & $\begin{array}{c}-0.23{ }^{\circ} \\
(-1.81)\end{array}$ & $\begin{array}{l}-0.05 \\
(-4.07)\end{array}$ & & $\begin{array}{c}-0.16^{\circ} \\
(-1.67)^{\circ}\end{array}$ & & $\begin{array}{l}0.081 \cdots " \\
(2.57)\end{array}$ & $\begin{array}{l}-0.006 \\
(-2.89)\end{array}$ & & & & & $\begin{array}{r}0.001 \\
(0.28)\end{array}$ & & & & 77 & & 1103 \\
\hline
\end{tabular}

- The lest ataliatic, which is distributed chi-equared, mentures equalily of coefficients between probil and truncaled regressions.

a...




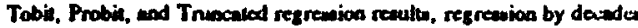

(T-Stutivition in parentheres)

Depreades veriebles per copiula gromtb

Coneene Exchenge

\begin{tabular}{|c|c|c|c|c|c|c|c|c|c|c|c|c|c|c|c|c|c|c|c|}
\hline & & Consuene & $\begin{array}{l}\text { Exchenge } \\
\text { Reve } \\
\text { Premiumen }\end{array}$ & $\underset{\text { tion }}{\ln f}$ & $\begin{array}{l}\text { Public } \\
\text { laveatmi } \\
\text { abre of } \\
\text { GDP }\end{array}$ & $\begin{array}{l}\text { Gov't } \\
\text { expend. } \\
\text { on educ } \\
\text { share (IDP }\end{array}$ & $\begin{array}{l}\text { Initial } \\
\text { level } \\
\text { of ine } \\
\text { per capp }\end{array}$ & $\begin{array}{l}\text { Squuare of } \\
\text { Ininial lev } \\
\text { of inc } \\
\text { per cap }\end{array}$ & $\begin{array}{l}\text { Gov't } \\
\text { coneminop. } \\
\text { share of } \\
\text { GDP }\end{array}$ & $\begin{array}{l}\text { Labor forrx } \\
\text { growth }\end{array}$ & $\begin{array}{l}\text { Finen- } \\
\text { cial } \\
\text { Dumuny }\end{array}$ & $\begin{array}{l}\text { Time } \\
\text { dummy } \\
1960 \text {. }\end{array}$ & $\begin{array}{l}\text { Time } \\
\text { durnmy } \\
1970 \text {. }\end{array}$ & Ausin & $\begin{array}{l}\text { Africa } \\
\text { dunumy }\end{array}$ & $\begin{array}{l}\text { Lenio } \\
\text { Arscrica } \\
\text { dumuny }\end{array}$ & $\begin{array}{l}\text { Sample } \\
\text { Size }\end{array}$ & 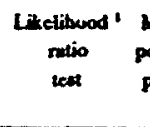 & $\begin{array}{l}\text { Meximoum } \\
\text { point w.s.s. } \\
\text { per ceppin } \\
\text { invome }\end{array}$ \\
\hline \multirow[t]{4}{*}{ v. } & Tobik & $\begin{array}{r}-0.26 \\
(-1.37)\end{array}$ & $\begin{array}{c}-0.034000 \\
(-3.69)\end{array}$ & $\begin{array}{l}-0.0560 .00 \\
(-3.70)\end{array}$ & $\begin{array}{r}0.007 \\
(0.067)\end{array}$ & & $\begin{array}{c}0.074 \\
(1.58)\end{array}$ & $\begin{array}{c}-0005 \\
(-1.61)\end{array}$ & & & & & $\begin{array}{l}0.014 \cdots \\
(3.16)\end{array}$ & & & & 95 & 55.920 .00 & - 2452 \\
\hline & Probin & $\begin{array}{l}33.86 \\
(0.82)\end{array}$ & $\begin{array}{c}-2.44 \\
(-1.30)\end{array}$ & $\begin{array}{l}-12.46 \cdots \\
(-2.37)\end{array}$ & $\begin{array}{l}45.2800 \\
(2.26)\end{array}$ & & $\begin{array}{r}-10.778 \\
(-1.01)\end{array}$ & $\begin{array}{r}0.809 \\
(1.17)\end{array}$ & & & & & $\begin{array}{l}9.15 \bullet \bullet \\
(2.39)\end{array}$ & & & & 95 & & $m^{2}$ \\
\hline & Adj. Prob. & 0.46 & -0.04 & $0.17 \cdots$ & $\quad 0.62 \cdots$ & & -0.148 & 0.011 & & & & & $0.12 \cdots$ & & & & & & \\
\hline & Trupculd & $\begin{array}{l}-0.50 * 01 \\
(-3.20)\end{array}$ & $\begin{array}{c}0.04 \\
(-3.09)\end{array}$ & $\begin{array}{c}-0.03 \\
(-1.22)\end{array}$ & $\begin{array}{l}-0.18 * 0 \\
(-2.03)\end{array}$ & & $\begin{array}{l}0.1499^{\circ \cdots} \\
(3.78)\end{array}$ & $\begin{array}{l}-0.009 \\
(-4.03)\end{array}$ & & & & & $\begin{array}{r}0.002 \\
(0.52)\end{array}$ & & & & 76 & & 1805 \\
\hline \multirow[t]{4}{*}{ vi. } & Tobin & $\begin{array}{r}-0.034 \\
(-0.36)\end{array}$ & $\begin{array}{l}-0.05 \\
(-8.67)\end{array}$ & & $\begin{array}{l}-0.03 \\
(-0.199)\end{array}$ & $\begin{array}{c}-0.08 \\
(-0.47)\end{array}$ & $\begin{array}{r}0.033 \\
(0.58)\end{array}$ & $\begin{array}{r}-0.002 \\
(-0.70)\end{array}$ & $\begin{array}{c}0.11 \\
(1.07)\end{array}$ & & & & $\begin{array}{l}0014^{\circ} \\
(2.53)\end{array}$ & & & & 82 & $39.84 \cdots$ & - $\quad 647$ \\
\hline & Probin & $\begin{array}{l}31.51 \\
\text { (1..31) }\end{array}$ & $\begin{array}{l}-6.78 \cdots \\
(-3.17)\end{array}$ & & $\begin{array}{l}26.79 \bullet \\
(1.83)\end{array}$ & $\begin{array}{l}-17.73 \\
(-0.94)\end{array}$ & $\begin{array}{r}-8.934 \\
(-1.45)\end{array}$ & $\begin{array}{r}0.574 \\
(1.44)\end{array}$ & $\begin{array}{l}25.05 \cdot \\
(1.94)\end{array}$ & & & & $\begin{array}{l}2.70 \bullet \bullet \\
(2.80)\end{array}$ & & & & 82 & & $2407^{2}$ \\
\hline & Adj. Prob. & 0.48 & $-0.10 \cdots$ & & $0.41 \bullet$ & -0.27 & -0.137 & 0.009 & $0.38^{\circ}$ & & & & $0.12 \cdots$ & & & & & & \\
\hline & Truacatod & $\begin{array}{c}-0.27 \\
(-1.47)\end{array}$ & $\begin{array}{l}-0.05 \cdots 0 \\
(-3.64)\end{array}$ & & $\underset{(-2.17)}{-0.23 \cdots}$ & $\begin{array}{c}0.28 \\
(1.16)\end{array}$ & $\begin{array}{l}0.095 \cdots \\
(2.14)\end{array}$ & $\begin{array}{l}-0.007 \cdots \\
(-2.40)\end{array}$ & $\begin{array}{c}-0.04 \\
(-0.2 B)\end{array}$ & & & & $\begin{array}{l}-0.002 \\
(-0.35)\end{array}$ & & & & 65 & & 940 \\
\hline
\end{tabular}

- The rea salixic, which is diatributed chi-equared, measures equality of cocfficiems between probit and inuncated regretuions.

2 Minimum nol maximum. 


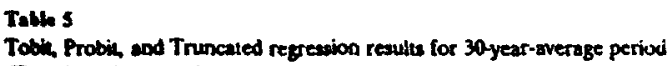

Tobke Probin, and Truncaled

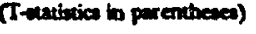

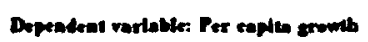

Constant Exchange Infation

\begin{tabular}{|c|c|c|c|c|c|c|c|c|c|}
\hline $\begin{array}{l}\text { Initial } \\
\text { teved } \\
\text { of tocome } \\
\text { per copita }\end{array}$ & $\begin{array}{l}\text { Square of } \\
\text { initial kvel } \\
\alpha \text { income } \\
\text { per capita }\end{array}$ & $\begin{array}{l}\text { Government } \\
\text { compuroption } \\
\text { chare of GDP }\end{array}$ & $\begin{array}{l}\text { labor } \\
\text { foroe } \\
\text { growth }\end{array}$ & $\begin{array}{l}\text { Gicur exp } \\
\text { on edvaldon } \\
\text { share of } \\
\text { GDP }\end{array}$ & $\begin{array}{l}\text { Acin } \\
\text { duturany }\end{array}$ & Africa & $\begin{array}{l}\text { Letio } \\
\text { America } \\
\text { oumary }\end{array}$ & $\begin{array}{c}\text { Sumple } \\
\text { Sare }\end{array}$ & $\begin{array}{c}\text { Likelibood } \\
\substack{\text { tio } \\
\text { ted }}\end{array}$ \\
\hline
\end{tabular}

\begin{tabular}{|c|c|c|c|c|c|c|c|c|c|c|c|c|}
\hline \multirow[t]{4}{*}{1} & Tobit & $\begin{array}{c}0.012 \\
(1.36)\end{array}$ & $\begin{array}{l}-0,02 \cdot \bullet \\
(-231)\end{array}$ & $\begin{array}{l}-0.003 \\
(-09)\end{array}$ & $\begin{array}{r}-0.05 \\
(-0.9)\end{array}$ & $\begin{array}{r}0.003 \\
(1.16)\end{array}$ & & $\begin{array}{r}-0.003 \\
(-0.2)\end{array}$ & $\begin{array}{l}-a, B^{\prime \cdots} \\
(-28)\end{array}$ & $\begin{array}{l}a, 00^{\infty} \\
(-25)\end{array}$ & 60 & 7.56 \\
\hline & Probih & $\begin{array}{c}3.91 \\
(0.01)\end{array}$ & $\begin{array}{l}-1.78^{\circ \bullet} \\
(-22)\end{array}$ & $\begin{array}{c}0.23 \\
\text { (a.s5) }\end{array}$ & $\begin{array}{l}-10.83 \\
(-1.57)\end{array}$ & $\begin{array}{c}0.43 \\
(1.28)\end{array}$ & & $\begin{array}{l}0.38 \\
(0)\end{array}$ & $\begin{array}{c}-5.62 \\
(-0.01)\end{array}$ & $\begin{array}{c}-5.84 \\
(-001)\end{array}$ & 60 & \\
\hline & Adjueted Probit & 0.04 & $-0.02 *$ & 0.002 & -0.106 & 0.004 & & 0.004 & a.co & .006 & & \\
\hline & Truncated & $\begin{array}{c}\mathbf{a} 08 \\
(1.52)\end{array}$ & $\begin{array}{c}0.02 \\
(-1.55)\end{array}$ & $\begin{array}{r}-0.0099 \\
(-129)\end{array}$ & $\begin{array}{r}-0.006 \\
(-0.13)\end{array}$ & $\begin{array}{c}0.002 \\
(0.66)\end{array}$ & & $\begin{array}{r}-0.004 \\
(-0.36)\end{array}$ & $\begin{array}{c}-0.030 * \\
(-237)\end{array}$ & $\begin{array}{l}-0.02^{\circ *} \\
(-1.96)\end{array}$ & 48 & \\
\hline \multirow[t]{4}{*}{2} & Tobit & $\begin{array}{c}-0.01 \\
(-0.41)\end{array}$ & $\begin{array}{c}-a 00^{\circ} \\
(-1.86)\end{array}$ & $\begin{array}{l}0.000005 \\
(0,02)\end{array}$ & $\begin{array}{c}-0.01 \\
(-0.28)\end{array}$ & $\begin{array}{c}00006 \\
(1.49)\end{array}$ & & & & & $\infty$ & 4.17 \\
\hline & Probit & $\begin{array}{c}-217 \\
(-107)\end{array}$ & $\begin{array}{c}-1.47 \% \\
(-2.04)\end{array}$ & $\begin{array}{c}0.24 \\
(0.92)\end{array}$ & $\begin{array}{c}-5.44 \\
(-1.21)\end{array}$ & $\begin{array}{c}0.47 \\
(1.47)\end{array}$ & & & & & $\infty$ & \\
\hline & Adjuated Probit & .003 & $-0.020^{\circ}$ & aOP & $-A 0 B$ & 0.007 & & & & & & \\
\hline & Truncaled & $\begin{array}{l}0,02 \\
(a s s)\end{array}$ & $\begin{array}{l}a(007 \\
(-0,9)\end{array}$ & $\begin{array}{r}-0.005 \\
(-076)\end{array}$ & $\begin{array}{l}a .05 \\
(a .5)\end{array}$ & $\begin{array}{c}0.006 \\
(1.16)\end{array}$ & & & & & 48 & \\
\hline \multirow[t]{4}{*}{3.} & Tobih & $\begin{array}{l}0.04 \\
(1.39)\end{array}$ & $\begin{array}{c}-0.0200 \\
(-243)\end{array}$ & $\begin{array}{r}-0.004 \\
(-133)\end{array}$ & & & $\begin{array}{l}a 2800 \\
(24)\end{array}$ & $\begin{array}{r}0.001 \\
(0.15)\end{array}$ & $\begin{array}{l}-0020 * \\
(-215)\end{array}$ & $\begin{array}{c}-002 \\
(-193)\end{array}$ & se & 9.95 \\
\hline & Probit & $\begin{array}{c}4.03 \\
(0.01)\end{array}$ & $\begin{array}{r}-1.5 \% \\
(-1.91)\end{array}$ & $\begin{array}{c}a 02 \\
(0.06)\end{array}$ & & & $\begin{array}{c}7.53 \\
(0.48)\end{array}$ & $\begin{array}{c}0.13 \\
(0.001)\end{array}$ & $\begin{array}{c}-5.11 \\
(-0.01)\end{array}$ & $\underset{(-0.01)}{-72}$ & 54 & \\
\hline & Adjusted Probit & $A B B$ & $-0.01^{\circ}$ & 0.002 & & & 0.005 & 0.0037 & 0.04 & e.04 & & \\
\hline & Truncated & $\begin{array}{c}a 06 \\
(1.46)\end{array}$ & $\begin{array}{r}0.02 \\
(-1.5)\end{array}$ & $\begin{array}{r}-0.000 \\
(-1.21)\end{array}$ & & & $\begin{array}{c}0296^{\circ} " \\
(232)\end{array}$ & $\begin{array}{l}0.0005 \\
(0.00)\end{array}$ & $\begin{array}{l}0.020 * \\
(-231)\end{array}$ & $\begin{array}{l}0.00^{-*} \\
(-23)\end{array}$ & 4 & \\
\hline \multirow[t]{4}{*}{ 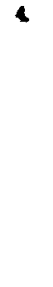 } & Tobat & $\begin{array}{r}-a 005 \\
(-a 19)\end{array}$ & $\begin{array}{c}-0.02^{\circ *} \\
(-23)\end{array}$ & $\begin{array}{l}-0.001 \\
(-0.3)\end{array}$ & & & $\begin{array}{r}0.396 \\
(1.76)\end{array}$ & & & & sa & 499 \\
\hline & Probili & $\begin{array}{c}-1.84 \\
(-a .93)\end{array}$ & $\begin{array}{c}-1.4 i^{* *} \\
(-1.9 n)\end{array}$ & $\begin{array}{l}a .196 \\
(a n)\end{array}$ & & & $\begin{array}{l}10.46 \\
(0.68)\end{array}$ & & & & 54 & \\
\hline & Adjustod Probia & -0.02 & $-0.02 *$ & 0.002 & & & 0.13 & & & & & \\
\hline & Truncesed & $\begin{array}{c}0.03 \\
(0.81)\end{array}$ & $\begin{array}{l}-0.01 \\
(-2.01)\end{array}$ & $\begin{array}{c}-0.004 \\
(-0.97)\end{array}$ & & & $\begin{array}{r}0.42^{\circ} \\
(1.93)\end{array}$ & & & & 13 & \\
\hline
\end{tabular}


Talk $I$ (continued)

Tobie Probit, and Truncated regreasion roults for 30year-average penod

(T-astibtio in parentheses)

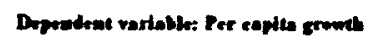

Constant Euchange Inlation

Initial
level
of income

\section{Square of}

initial level

or income

Government

Letor

Sabor
force
cownh

Gon ex

an education

Gore of

Ara

Afno

Lain

Lain Sample

dummy

Litelibood

\begin{tabular}{|c|c|c|c|c|c|c|c|c|c|c|c|c|}
\hline \multirow[t]{4}{*}{ s. } & Tobit & $\begin{array}{c}0.04 \\
\text { (123) }\end{array}$ & $\begin{array}{l}-0,020.0 \\
(-268)\end{array}$ & $\begin{array}{r}0.007 \\
(0.81)\end{array}$ & $\begin{array}{r}-0.005 \\
(-1.46)\end{array}$ & & $\begin{array}{l}02800 \\
(238)\end{array}$ & $\begin{array}{r}a 002 \\
(021)\end{array}$ & $\begin{array}{l}0.0200 \\
(-247)\end{array}$ & $\begin{array}{l}-0.020 \\
(-209)\end{array}$ & 52 & 11.86 \\
\hline & Prabie & $\begin{array}{c}3.72 \\
\text { (a.03) }\end{array}$ & $\begin{array}{l}-2244^{\circ} \\
(-203)\end{array}$ & $\begin{array}{l}\text { 1.67 } \\
\text { (L1) }\end{array}$ & $\begin{array}{c}-0.04 \\
(-0.1)\end{array}$ & & $\begin{array}{l}1213 \\
(0.73)\end{array}$ & $\begin{array}{l}08 \\
(0001)\end{array}$ & $\begin{array}{c}529 \\
(-0.01)\end{array}$ & $\begin{array}{c}-5.05 \\
(-0.01)\end{array}$ & $\$ 2$ & \\
\hline & Adjuated Probil & 0.03 & -0.020 & 0.014 & -0.0003 & & 0.10 & 20008 & -005 & oos & & \\
\hline & Trancated & $\begin{array}{c}0.06 \\
\text { (1.52) }\end{array}$ & $\begin{array}{l}-a 02^{\circ *} \\
(-2.1)\end{array}$ & $\begin{array}{r}0.003 \\
(0.53)\end{array}$ & $\begin{array}{r}-0008 \\
(-134)\end{array}$ & & $\begin{array}{c}025^{*} \\
(1.95)\end{array}$ & $\begin{array}{l}-0,00004 \\
(-0,005)\end{array}$ & $\begin{array}{l}-002^{\circ \bullet} \\
(-223)\end{array}$ & $\begin{array}{l}-0.0204 \\
(-228)\end{array}$ & 41 & \\
\hline \multirow[t]{4}{*}{ a } & Tobit & $\begin{array}{c}-0.04 \\
(-0.32)\end{array}$ & $\underset{(-226)}{-0.02 * *}$ & & $\begin{array}{c}0.02 \\
(0.47)\end{array}$ & $\begin{array}{r}-0.002 \\
(-0.56)\end{array}$ & $\begin{array}{l}028^{\circ *} \\
(239)\end{array}$ & $\begin{array}{r}a 001 \\
(a .11)\end{array}$ & $\frac{0.02+*}{(-2.29)}$ & $\begin{array}{r}-0.02 \\
(-1.87)\end{array}$ & 54 & 10.05 \\
\hline & Probit & $\begin{array}{c}-5.36 \\
(-0.01)\end{array}$ & $\begin{array}{r}-1.46^{\circ} \\
(-1.76)\end{array}$ & & $\begin{array}{c}27 \\
(0.61)\end{array}$ & $\begin{array}{r}-0.19 \\
(-0.6)\end{array}$ & $\begin{array}{c}6.75 \\
(0.43)\end{array}$ & $\begin{array}{l}0.3 \\
(0)\end{array}$ & $\begin{array}{c}-5.00 \\
\left(\begin{array}{l}1 \\
1\end{array}\right)\end{array}$ & $\begin{array}{c}-4.7 \\
(-0.0 ?)\end{array}$ & 54 & \\
\hline & Adjusted Probil & -0.05 & $-0.01^{\circ}$ & & 0023 & 0.0016 & 000 & $a 0028$ & -0.04 & -0.04 & & \\
\hline & Trunessed & $\begin{array}{c}0.02 \\
(0.01)\end{array}$ & $\begin{array}{c}-0.02 \\
(-1.16)\end{array}$ & & $\begin{array}{r}0.006 \\
(000)\end{array}$ & $\begin{array}{l}-0.0000 \\
(-0.14)\end{array}$ & $\begin{array}{l}030^{\circ 0} \\
(217)\end{array}$ & $\begin{array}{l}a 0004 \\
(a 0 \infty)\end{array}$ & $\begin{array}{r}-0,00 \\
(-1.93)\end{array}$ & $\begin{array}{l}-0.0200 \\
(-220)\end{array}$ & 43 & \\
\hline
\end{tabular}

- Significant at $10 \%$ keret 


\section{Variable Definition}

\section{Dependent variable:}

Per capita income growth $\quad=\log (1+$ growth $)$; SOURCE: World Bank Database.

Per cap income growth, PROBIT = dummy of per capita income growth; Equal to 0 if growth $<0.1$; 1 otherwise. SOURCE: World Bank Database.

Per cap income growth, TOBIT = Equal to 0 if growth $<0.1$; ' $g$ ' otherwise, where ' $g$ ' is the growth and TRUNCATED rate. In the truncated regressions, the $g<0.1 \%$ observations are excluded. SOURCE: World Bank Database.

Independent variables:

Exchange rate premium

$=\log (1+$ black market exchange rate premium $)$;

SOURCES: 1960-83: World Currency Yearbook; 1984: Pick's Currency Yearbook (various years), 1984-89: Financial Times International Reports' Statistical Market Letter, 1989: Africa Analysis for certain countries.

Inflation

$=\log (1+$ inflation rate); SOURCE: World Barin Database.

Fablic Investment, share of GDP $=\log (1+$ real public investment as a share of GDP); SOURCE: Pfefferman, G. and A. Madarassy. "Trends in Private Investment in Developing Countries". IFC Discussion Paper No. 11, World Bank (1989).

Initial level of income per capita

$=\log$ (GDP per capita income) initial year for each decade, i.e., 1960 for the 60 's, 1970 for the 70 's, 1980 for the 80 's. SOURCE: Summers and Heston.

Government consumption as a share of GDP

$=\log (1+$ real government consumption as a share of GDP);

SOURCE: World Bank Database.

Labor force growth

= Average annual growth rate of population of working age (15-64). Based on data in World Development Indicators, World Rank (1987).

Government expenditure on $=\log (1+$ nominal government expenditure on education as a share education, share of GDP of GDP). SOURCE: World Bank Database.

\section{Dummy Variables:}

Financial Dummy

$=$ Dummy variable for financial policy distortions. 1 if real interest rates are less than $-5 \%, 0$ otherwise. Based on World Development Report 1989. Data from-1965-85 from Financial Policy Division, World Bank. 


\section{BIBLIOGRAPHY}

Abramowitz, Moses. 1989. Thinking about Growth. Cambridge: Cambridge University Press.

Andrews, Donald W. K. 1989. "Power in econometric applications." Econometrica 57 (Sep.): pp.1059-1090.

Azariadis, C. and A Drazen. 1990. "Threshold Externalities in Economic Development." Quarterly Journal of Economics 105: pp. 501-26.

Balassa, Bela. 1985. "Exports, Policy Choices, and Economic Growth in Developing Countries After the 1973 Oil Shock." Joumal of Development Economics 18 p. 23-35.

Barro, Robert. 1990. "Government Spending in a Simple Model of Endogenous Growth. "Journal of Political Economy 98: pp. S103-S125.

- 1991 "Economic Growth in a Cross Section of Countries."Quarterly Journal of Economics. (same as De Long and Summers), pp. 407-444.

and Xavier Sala-i-Martin. 1989. "Economic Growth and Convergence Across the United States." Harvard University.

and _ 1990. "Public Finance in Models of Economic Growth." NBER Working Paper No. 3362. Cambridge, MA: NBER.

Baumol, William and E. Wolff. 1988. "Productivity Growth, Convergence, and Welfare: Reply." American Economic Review. December.

Becker, Gary S. and Robert Barro. 1988. "A reformulation of the economic theory of fertility." Quarterly Journal of Economics 103 (Feb.): pp. 1-25.

Kevin Murphy, and Robert Tamura. 1990. "Human Capital,Fertility, and Economic Growth." Joumal of Political Economy 98(5).

De Long, J. B. and L. H. Summers. 1991. "Equipment, Investment, Relative Prices, and Economic Growth." Quarterly Journal of Economics, May 1991, Vol CVI, Issue 2, pp. 445. 502.

Diamond, J. 1989. "Government Expenditure and Economic Growth: An Empirical Investigation." IMF Working Paper No. 89/45. Washington, DC: MMF.

Dollar, David. 1990 "Outward-oriented countries do grow more rapidly". Mimeo, World Bank.

Easterly, William. 1990a. "How Does Growth Begin? Models of Endogenous Development." World Bank. 
- 1990b. "Endogenous Growth in developing countries with government-induced distortions." World Bank.

. R. King, R. Levine, and S. Rebelo. 1990. "Do national policies affect long-run growth? A research agenda." World Bank.

Fischer, Stanley. 1991. "Growth, Macroeconomics and Development," NBER Macroeconomics, Cambridge, MA (forthcoming).

Gale, and Sutherland. 1968. "Analysis of a one good model of economic development." In Dantzig, George B. and Arthur F. Veinott, Jr. Mathematics of the decision sciences Part II. Providence: American Mathematical Society. 1968.

Gelb, Alan. H. 1989. "Financial policies, growth, and efficiency." PPR Working Paper No. 202. Washington, DC: World Bank.

Gerschenkron, Alexander. 1962. Economic Backwardness in Historical Perspective, Cambridge MA, Harvard University Press.

Greene, W.H. 1990 Econometric An. ysis. New York: MacMillan.

Grier, Kevin and Gordon Tullock. 1989. "An Empirical Analysis of Cross-National Economic Growth, 1951-1980." Journal of Monetary Economics 24:p.259-276.

Heston, Alan and Robert Summers. 1988. "What We Have Learned about Prices and Quantities from International Comparisons: 1987." American Economic Review 78(2): 467-473.

Jones, Larry and Rodolfo Manuelli. 1990. "A ' 'onvex Model of Equilibrium Growth." Journal ofPolitical Economy. 98 (5): pp. 1008-38.

Jorgenson, Dale W. 1961. "The development of a dual economy." Economic Journal 71 (Jun):pp. 309-334.

Jovanovic, B. and S. Lach. 1990. "The diffusion of technology and inequality among nations." Paper presented at a NBER conference on economic growth, November 1990.

King, Robert, and Sergio Rebelo. 1990. "Public Policy and Economic Growth: Developing Neoclassical Implications." Journal of Political Economy 98: pp. S126-150.

Kurz, M. 1968. "The general instability of a class of competitive growth processes." Review of Economic Studies 35 (Mar) : pp. 155-174.

Landau, Daniel. 1986. "Government and Economic Growth in the Less Developed Countries: An Empirical Study for 1960-80." Economic Development and Cultural Change 35 (October) p.35-75.

Levine, Ross, and David Renelt. 1990a. "A Sensitivity Analysis of Cross-Country Growth Regressions." World Bank. 
Lucas, Robert. 1988. "On the Mechanics of Economic Development." Journal of Monetary Economics 22 (July) p.3-42.

Mankiw, N. Gregory, David Romer. and David Weil. 1990. "A Contribution to the Empirics of Economic Growth." Harvard University.

Murphy, Kevin, Andrei Shleifer, and Robert Vishny. 1989. "Industrialization and the Big Push." Journal of Political Economy 97 (October) p.1003-1026.

1991. "The allocation of talent: implications for growth," Quarterly Journal of Economics, May 1991, Vol CVI, Issue 2, pp. 503-530.

Nelson, Richard R. 1956. "A theory of the low-level equilibrium trap in underdeveloped economies." American Economic Review 41: pp. 894-908.

Parente, Stephen L. and Edward G. Prescott. (1991) "Technology Adoption and Growth," NBER WP\#3733

Rebelo, Sergio. 1991a forthcoming. "Long run policy analysis and long run growth." Journal of Political Economy.

. 1991b. "Growth in open economies." World Bank.

Renelt, David. 1591. "Economic Growth: A Review of the Theoretical and Empirical Literature" Word Bank PRE Working Paper 678.

Reynolds, Lloyd G. 1985. Economic Growth in the Third World, 1850-1980. New Haven and London: Yale University Press.

Romer, Paul. 1986. "Increasing Returns and Long-Run Growth." Journal of Political Economy.94 p.1002-1037.

1989. "What determines the rate of growth of technological change?" PPR Working Paper No. 279. Washington, DC: World Bank.

. 1990. "Endogenous technological change." Journal of Political Economy 98: pp. S71-S102.

Rosenstein-Rodan, P.N. 1943. "Problems of Industrialisation of eastern and south-eastern Europe." Economic Journal 53:pp. 202-211.

Roubini, Nouriel and Xavier Sala-I-Martin. 1991. The Relation Between Trade Regime, Financial Development and Economic Growth." NBER Fourth Annual Interamerican Seminar on Economics

Sala-I-Martin, Xavier. 1990 . "Lecture notes on economic growth (1): Introduction to literature and neoclassical models." NBER Working Paper No. 3563. Cambridge, MA: NBER.

Taylor, Lance. 1989. Stabilisation and Growth in Developing Countries: A Structuralist 
Approach. London: Harwood Academic Publishers.

Wan, Henry. 1990. "Trade, development and inventions." World Bank seminar.

Young, Alwyn. 1991. "Learning by Doing and the Dynamic Effects of International Trade," Quarterly Journal of Economics, May 1991, Vol CVI, Issue 2, pp. 369-406. 
Inte

WPS771 Macroeconomic Structure and Policy in Zimbabwe: Analysis and Empirical Model (1965-88)

WPS772 Macroeconomic Adjustment to Oil Shocks and Fiscal Reform: Sim:slations for Zimbabwe, 1988-95

WPS773 Are Gihana's Roads Paying Therr Way" Assessing Road Use Cost and User Cl:arges in Ghana

WPS774 Agricultural Pricing Systems and Transponation Policy in Africa

WPS775 The Macroeconomics of Public Sector Deficits: A Synthesis

WPS776 Enforcement of Canadian "Unfair" Trade Laws: The Case for Competition Policies as an Antidote for Protection

WPS777 Do the Benefits of Fixed Exchange Rates Outweigh Their Costs? The Franc Zone in Africa

WPS778 A Dynamic Bargaining Model of Sovereign Debt Development and Research Training in Human Reproduction

WPS780 Optimal User Charges and Cost Recovery for Roads in Developing Countries

WPS781 The Korean Consumer Electronics Industry: Reaction to Antıdumping Actions

WPS782 The Economic Effects of Widespread Application of Antidumping Duties to Import Pricing

WPS783 The Origins and Evolution of Antidumping Regulation

WPS784 Chemicals from Poland: A Tempest in a Teacup
Eduardo Fernandez-Arias

Shantayanan Devarajen Dani Rodrik

October 1991

William Easterly

Klaus Schmidt-Hebbel

Mark A. Dutz

October 1991

October 1991

Janet Nassim

October 1991

J. Michael Finger

October 1991

N. Artis 37947

Contact

for paper

S. Jonnakuty 39074

S. Jonnakuty 39074

J. Francis 35205

B. Gregory 33744

R. Martin 39065

N. Artis

37947

A. Bhalla 37699

S. King-Watson 31047

O. Nadora 31019

$\operatorname{lan}$ G. Heggie

October 1991

P. Cook 33462

Taeho Bark

October 1991

N. Artis 37947

Octcber 1991

N. Artis 37947

Andrzej Olechowskı

October 1991

N. Artis

37947 
Policy Research Working Paper Series

Inte

WPS785 $\begin{aligned} & \text { How Did the Asian Countries Avold } \\ & \text { the Debt Crisis? }\end{aligned}$
WPS786 $\begin{aligned} & \text { Fiscal Policy for Managing } \\ & \text { Indonesia's Environment }\end{aligned}$
WPS787 $\begin{aligned} & \text { Private Investment Under Macroeco- } \\ & \text { nomic Adjustment in Morocco }\end{aligned}$
WPS788 $\begin{aligned} & \text { How Expectations Affect Reform } \\ & \text { Dynamics in Developing Countries }\end{aligned}$
WPS789 $\begin{aligned} & \text { Intrahousehold Inequality and the } \\ & \text { Theory of Targeting }\end{aligned}$
WPS790 $\begin{aligned} & \text { Reforming and Privatizing Hungary's } \\ & \text { Road Haulage }\end{aligned}$

WPS791 Measuring Real Exchange Rate Instability in Developing Countries:

Empirical Evidence and Implications

WPS792 Reducing Labor Redundancy in State-Owned Enterprises

WPS793 Decollectivization and the Agricultural Transition in Eastern and Central Europe

WPS794 How: Do Natınal Policies Affect Long-Run Growth? A Research Agenda

WPS795 Economic Stagnation, Fixed Factors, and Policy Thresholds
Author

Sadiq Ahmed

Tobias Muller

Francesco Daveri

Lawrence Haddad

Ravi Kanbur

Esra Bennathan

Jeffrey Gutman

Louis Thompson

Lant Pritchett

Jan Svejnar

Katherine Terrell

Karen M. Brooks

William Easterly

Robert King

Ross Levine

Sergio Rebelo

William Easterly
Date

October 1991

October 1991

October 1991

Contact

for paper

S. King-Watson 31047

B. Prasertwaree 82477

S. Jonnakuty 39074

October 1991

S. Jonnakuty 39074

October 1991

J. Sweeney 31021

October 1991

B. Gregory 33744

October 1991

K. Cabana 37947

October 1991

B. Gregory 33744

October 1991

C. Spooner 30464

October 1991

R. Martin 39065

October 1991
R. Martin 39065 